\title{
La revocatoria de las candidaturas, ¿un mecanismo de protección del derecho al sufragio? Análisis en las elecciones del Congreso de la República 2018-2022 ${ }^{* * * *}$
}

\section{Election lists recall a mechanism for suffrage rights: An analysis of 2018-2022 Congress elections in Colombia}

\section{RESUMEN}

En este trabajo se analiza la revocatoria de inscripción de las candidaturas y sus efectos en los derechos al sufragio pasivo y a la representación política. Para ello se estudiaron los 106 trámites de revocatoria de candidaturas que conoció el Consejo Nacional Electoral (CNE) con ocasión de las elecciones del Congreso de la República 2018-2022. Los casos se clasificaron de acuerdo con las condiciones para la presentación de listas de candidatos al Congreso de la República: (i) circunscripciones ordinarias; (ii) circunscripción especial de las comunidades afrodescendientes; (iii) circunscripción de las comunidades indígenas, y (iv) las curules de las FARC reconocidas en el Acto Legislativo 03 de 2017. Este estudio se confrontó con las acciones de

Docente-investigadora del Departamento de Derecho Constitucional de la Universidad Externado de Colombia (Bogotá, Colombia). Abogada de la Universidad Externado de Colombia y doctora en Derecho Constitucional de la Universidad de Alicante. Contacto: floralba.padron@ uexternado.edu.co ORCID: 0000-0002-7056-1028.

Docente-investigadora del Departamento de Derecho Constitucional de la Universidad Externado de Colombia (Bogotá, Colombia). Abogada con especialización en Derecho Público de la Universidad Externado de Colombia, magíster en Derecho Parlamentario, Elecciones y Técnica Legislativa de la Universidad Complutense de Madrid. Contacto: carolina.rico@ uexternado.edu.co ORCID: 0000-0002-8899-8009.

**** Abogado de la Universidad Externado de Colombia y candidato a magíster en Derecho Público de la Universidad Externado de Colombia. Contacto: juan.narvaez02@est.uexternado. edu.co ORCID: 0000-0002-2920-2357.

***** Recibido el 30 de agosto de 2019, aprobado el 12 de junio de 2020.

Para citar el artículo: Padrón Pardo, F., Rico Marulanda, C. y Narváez Quintero, J. S. La revocatoria de las candidaturas, ¿ un mecanismo de protección del derecho al sufragio? Análisis en las elecciones del Congreso de la República 2018-2022. En Revista Derecho del Estado, Universidad Externado de Colombia. N. ${ }^{\circ}$ 47, septiembre-diciembre de 2020, 31-78.

DoI: https://doi.org/10.18601/01229893.n47.02 
nulidad electoral promovidas ante la Sección Quinta del Consejo de Estado para el mismo período electoral, con el objeto de establecer coincidencias y determinar la utilidad de la coexistencia de dos mecanismos independientes con una finalidad similar.

PALABRAS CLAVE

Derechos políticos, sufragio pasivo, representación política, revocatoria de inscripción de candidaturas, nulidad electoral.

\section{ABSTRACT}

This chapter analyzes the revocation of the registration of candidates and its effects in passive suffrage and political representation. 106 cases for the revocation of candidacies, solved by the National Electoral Council (CNE), during the elections to the Congress of the Republic 2018-2022, were considered for the analysis. The cases were classified according to the conditions by which the lists of candidates for the Congress of the Republic were issued: (i) ordinary constituencies; (ii) special constituency of Afro-descendant communities; (iii) constituency of indigenous communities; and (iv) The FARC seats recognized in Constitutional Amendment 03 of 2017. This analysis is confronted with the electoral nullity actions solved by the Fifth Section of the State Council for the same electoral period, in order to establish coincidences and determine the utility of the coexistence between two independent mechanisms with a similar purpose.

\section{KEYWORDS}

Political rights, Passive suffrage, Political representation, Revocation of the registration of candidates, Electoral nullity.

SUMARIO

Introducción. 1. La revocatoria de inscripción de las candidaturas en el derecho electoral colombiano: los problemas que impone la puesta en marcha del mecanismo de control en nuestro ordenamiento constitucional. 1.1. Objeto, característica y competencia de la revocatoria. 1.2. Procedimiento y efectos. 2. Análisis de las solicitudes de revocatoria de inscripción de las candidaturas de las elecciones legislativas 2018-2022. 2.1. Las circunstancias ordinarias. 2.2. La circunscripción especial de las comunidades afrodescendientes. 2.3. La circunscripción especial indígena. 2.4. Las curules de las FARC reconocidas en el Acto Legislativo 03 de 2017. 3. Acciones de nulidad electoral promovidas en las elecciones legislativas 2018-2022. Conclusiones. Referencias. 


\section{INTRODUCCIÓN}

Con la Constitución de 1991 se buscó fortalecer la representación política mediante el reconocimiento del pluralismo político, la posibilidad de fundar partidos y movimientos, la ampliación de las organizaciones políticas, un sistema electoral basado en listas y cociente electoral, y el establecimiento de los miembros de las corporaciones de elección popular como servidores públicos.

A pesar de estos esfuerzos, en la realidad se observa un déficit de representación política debido a la ausencia de partidos políticos fuertes y de los elementos materiales para el funcionamiento adecuado de una democracia ${ }^{1}$. Esto ha generado conflictos entre las dimensiones activa y pasiva del derecho al sufragio, acentuados por la inexistencia de mandatos imperativos hacia los representantes ${ }^{2}$.

El establecimiento de los mecanismos para fortalecer la democracia en Colombia se adelantó en contravía de los intereses de los partidos tradicionales, generando divisiones en estos y sin acabar ni tampoco de garantizar los fines constitucionales ${ }^{3}$. Además, los mecanismos de participación ciudadana se desarrollaron bajo reglas rígidas que impiden su adecuado desarrollo y que no han servido para mejorar las relaciones Estado-sociedad ${ }^{4}$.

La falta de legitimidad, el déficit representativo y las malas prácticas de las organizaciones al postular candidaturas condujeron a replantear su papel en el sistema electoral. Así las cosas, en el diseño constitucional se ha establecido que la facultad de presentar candidaturas es una prerrogativa de las organizaciones políticas (art. 108), exigiéndoles responsabilidad y diligencia al avalar candidatos para participar en los comicios ${ }^{5}$. También se establecieron medidas para regular la organización interna de aquellas que deberán ajustar sus actuaciones a los principios de transparencia, objetividad, moralidad, equidad de género y publicidad de los programas políticos 6 .

Desde 2003 se han aprobado una serie de reformas constitucionales que incrementaron la responsabilidad de las organizaciones políticas en materia

1 PADRÓN PARDO, F. El concepto y función de las bancadas: las transformaciones de la representación política en Colombia. Bogotá: Universidad Externado de Colombia, 2015, 339-342.

2 Vanegas GiL, P. P. Las candidaturas en el derecho electoral colombiano. Bogotá: Universidad Externado de Colombia, 2009, 36.

$3 \quad$ Ibid., 341.

4 Ibid.

5 Rico Marulanda, C. El concepto de inhabilidad en el ordenamiento jurídico colombiano. En Revista Centro de Estudios Políticos del Ministerio del Interior y de Justicia. Vol. 5 , 2012, 109 ss.

6 PADRÓN PARDo, F. El fortalecimiento de los partidos políticos, ¿una tarea pendiente? En SteFAn, J. (ed.), 20 años de la Constitución colombiana: logros, retrocesos y agenda pendiente. Bogotá: Fundación Konrad Adenauer, 2012, 248. 
de transparencia y garantía de probidad de los candidatos. Ese año, mediante el Acto Legislativo 01, se establecieron nuevas reglas para las elecciones (listas únicas, umbrales y cifra repartidora) y sobre organización parlamentaria (bancadas, sanciones y prohibición de la doble militancia). Esto redujo la cantidad de organizaciones políticas y privilegió a las más fuertes y robus$\operatorname{tas}^{7}$. Por otra parte, en 2004 se definió una inhabilidad para quienes hubieran sido condenados penalmente y quisieran ocupar cargos de elección popular ${ }^{8}$.

En 2009, con el Acto Legislativo 01, se estableció en cabeza del Consejo Nacional Electoral (CNE) la competencia para revocar la inscripción de las candidaturas a corporaciones públicas y cargos de elección popular. Así, el CNE decide basado en la existencia de plena prueba de las inhabilidades y adelanta un proceso expedito observando las garantías del debido proceso. Sin embargo, el diseño de la revocatoria no contempla ninguna sanción para las organizaciones políticas, siendo por tanto incoherente con los fines buscados por las reformas constitucionales.

Paralelamente, se puede demandar la nulidad de los actos de elección y la pérdida de investidura ante la Sección Quinta del Consejo de Estado, incluso por causales idénticas a las de la revocatoria. Se trata de procesos que no se excluyen entre sí y que pueden en ocasiones generar debates y conclusiones asimétricas.

A pesar de las intenciones mencionadas, la revocatoria de inscripción de candidaturas no ha cerrado el debate sobre las calidades y requisitos que deben acreditar los candidatos al Congreso de la República. No se han documentado conclusiones sobre una mejoría en las relaciones ciudadanos-representantes, ni en lo que concierne al déficit de representación política.

Por lo anterior, el presente escrito pretende analizar si este mecanismo ha servido para garantizar el derecho al sufragio en sus dimensiones activa y pasiva. Se tratará de establecer si permite realizar una depuración adecuada de las candidaturas y dar certeza al electorado de que los elegidos no defraudarán su confianza, al verse afectados por una eventual declaratoria de nulidad electoral o una pérdida de investidura.

De esta forma se busca confirmar la hipótesis según la cual esta herramienta de control jurídico es insuficiente para solucionar los problemas estructurales del sistema electoral colombiano y garantizar el ejercicio de los derechos políticos. Con miras a resolver el problema jurídico (i) haremos un análisis de los 106 trámites de revocatoria de candidaturas que conoció

$7 \quad$ El efecto de la puesta en marcha de las modificaciones del sistema electoral ha sido la disminución de los partidos y movimientos. Después de las elecciones 2006, de las 62 organizaciones políticas existentes solo 17 conservaron la personería jurídica; y luego de las elecciones de 2016, la mantuvieron 12 partidos y movimientos políticos. Al respecto cfr. Consejo Nacional Electoral. Resolución 1057 del 13 de julio de 2006.

8 El Acto Legislativo 01 de 2004 hace referencia a sentencia judicial, bien por la comisión de delitos o en el marco de la condena en un proceso de responsabilidad del Estado. 
el CNE con ocasión de la elección del Congreso de la República 2018-2022 y (ii) analizaremos si estas decisiones contribuyen a garantizar los derechos políticos y el diseño de la representación política en Colombia.

En este orden de ideas, clasificamos los procesos de revocatoria teniendo en cuenta las condiciones especiales para la presentación de listas de candidatos al Congreso de la República. Estas condiciones están relacionadas con las circunscripciones electorales para la elección de las cámaras legislativas.

Se dividieron los casos en cuatro categorías, así:

(i) Las circunscripciones ordinarias: se estudiaron los 59 procesos para revocar la candidatura de personas avaladas por organizaciones políticas que participaban en las circunscripciones ordinarias del Congreso de la República. En particular, se analizó la afectación a los derechos políticos y si el mecanismo ha permitido que las organizaciones políticas cumplan con un nivel mínimo de diligencia para garantizar la probidad de sus candidatos.

(ii) La circunscripción especial de las comunidades afrodescendientes: se analizaron las 34 solicitudes de revocatoria y los criterios aplicados por el CNE para revocar o no las candidaturas presentadas por las comunidades afrodescendientes. Se procedió a determinar si tales criterios resultaban suficientes y si eventualmente con ellos se limitaron injustificadamente los derechos políticos y la autonomía política de estas comunidades.

(iii) La circunscripción de las comunidades indígenas: se estudiaron los 2 casos en los cuales se podía apreciar, por un lado, la existencia de una inhabilidad, y por otro, el debate sobre si una organización puede presentar listas de manera simultánea en la circunscripción ordinaria y en la de las comunidades indígenas.

(iv) Las curules de las FARC reconocidas en el Acto Legislativo 03 de 2017: se estudiaron los criterios de acuerdo con los cuales el CNE resolvió los 11 casos de solicitudes de revocatoria presentadas respecto de las candidaturas inscritas por el partido FARC.

Finalmente, se confrontan estos procesos con las acciones de nulidad electoral promovidas ante la Sección Quinta del Consejo de Estado para el mismo período, en contra de los candidatos electos en la jornada electoral correspondiente con el objeto de establecer coincidencias entre los procesos y determinar la utilidad de la existencia de dos procesos independientes que persiguen un objetivo similar: que al Congreso de la República lleguen personas probas, que cumplan con todo los requisitos constitucionales y legales exigidos, y que se respete el diseño de la representación política. 
1. LA REVOCATORIA DE INSCRIPCIÓN DE LAS CANDIDATURAS

EN EL DERECHO ELECTORAL COLOMBIANO: LOS PROBLEMAS

QUE IMPONE LA PUESTA EN MARCHA DEL MECANISMO DE

CONTROL EN NUESTRO ORDENAMIENTO CONSTITUCIONAL

Con el objetivo de proteger la moralidad administrativa, la probidad en el ejercicio de cargos de elección popular, la igualdad de las candidaturas y la libertad de la elección, se otorgó al CNE la facultad de revocar la inscripción de los candidatos a corporaciones públicas y a cargos de elección popular cuando exista plena prueba de que aquellos están incursos en causales de inhabilidad constitucional o legal (num. 12 art. $265 \mathrm{CP}$ ).

La dificultad que comporta la inhabilidad como causal para revocar la inscripción de un candidato es su origen. Al ser una limitación de derechos fundamentales, las causales deben ser definidas previamente en el ordenamiento, junto con el tipo de autoridad que puede válidamente limitar el ejercicio del derecho a ser elegido.

Adicionalmente, pueden surgir tensiones respecto de la interpretación que el CNE haga sobre las inhabilidades. Se trataría de tensiones referidas a si, por tratarse de causales de carácter taxativo, aquel puede hacer un ejercicio de interpretación sobre estas o si, por el contrario, solo debe hacer una labor de constatación de su existencia, y en este último caso únicamente debería verificar la existencia de plena prueba para determinar la configuración de las causales y proceder a revocar la inscripción de las candidaturas.

En nuestro diseño constitucional encontramos preceptos constitucionales y legales que atribuyen competencias a varias autoridades administrativas y órganos de control para limitar el derecho a ser elegido. El artículo 278 numeral $1 \mathrm{CP}$ otorga facultades a la Procuraduría General de la Nación para imponer sanciones a los funcionarios públicos que incurran en faltas disciplinarias, como la desvinculación del cargo, la cual comporta una inhabilidad para el ejercicio de cargos y funciones públicas ${ }^{9}$. Por otro lado, el artículo 268 numeral $5 \mathrm{CP}$ atribuye a la Contraloría General de la República competencia para declarar responsable fiscalmente a una persona, generando también una inhabilidad para el acceso a cargos públicos ${ }^{10}$.

Estas competencias pueden generar contradicciones con el marco de protección establecido en el Sistema Interamericano de Derechos Humanos (arts. 8 y 23 de la Convención Americana de Derechos Humanos), según

9 Esta facultad sancionatoria de carácter disciplinario se encuentra desarrollada en la Ley 734 de 2002, por medio de la cual se expide el Código Disciplinario Único.

10 Esta facultad sancionatoria de carácter fiscal está desarrollada en las leyes 610 de 2000, por medio de la cual se establece el trámite de los procesos de responsabilidad fiscal de competencia de las contralorías, y 1474 de 2011, por medio de la cual se dictan normas orientadas a fortalecer los mecanismos de prevención, investigación y sanción de actos de corrupción y la efectividad del control de la gestión pública. 
el cual los derechos políticos solo pueden ser limitados por un juez penal y respetando el derecho de defensa y el debido proceso ${ }^{11}$. Esta posición no es compartida en su totalidad por la Corte Constitucional colombiana, la cual ha encontrado ajustada a la Constitución la competencia de establecer inhabilidades por sanciones fiscales ${ }^{12}$. Así, la Corte Constitucional ha manifestado que el artículo 23 del Pacto de San José de Costa Rica no restringe la capacidad de los Estados para adoptar medidas que limiten el acceso a cargos públicos con el fin de combatir la corrupción, siendo posible el ejercicio de las respectivas competencias siempre que se respeten la Constitución y las normas internacionales, en especial las de derechos humanos.

Ante este contraste con la Convención Americana en materia de inhabilidades cabe preguntarse: ¿cuál es la postura que debe asumir el CNE? ¿Ha de apartarse de la posición de la Corte Constitucional y hacer su propio juicio de convencionalidad? De ser así, no se podrían tener en cuenta los informes remitidos por la Procuraduría General de la Nación en los que se pone de manifiesto la existencia de candidatos inhabilitados por la existencia de sanciones de carácter disciplinario o fiscal.

También cabe cuestionarse si una posición en tal sentido podría generar un escenario de incumplimiento de los tratados internacionales de lucha contra la corrupción, como la Convención Interamericana de Lucha contra la Corrupción. Lo anterior desconocería los fines esenciales del Estado en materia de garantía de la moralidad pública, de la transparencia y de la correcta gestión y ejecución de los recursos del Estado. Por último, la aplicación preferente de la línea jurisprudencial de la Corte Interamericana puede dar lugar a la apertura de procesos penales por prevaricato o procedimientos disciplinarios por desconocimiento del ordenamiento jurídico interno.

Se trata de un debate complejo, el cual no se encuentra cerrado y que obliga a repensar las reglas para el ejercicio del derecho político a ser elegido y sus limitaciones, así como a reflexionar sobre la manera de establecer mayores garantías procesales en los procesos disciplinarios y fiscales, en los que se

11 Posición que encuentra sustento en el fallo López Mendoza vs. Venezuela. En este pronunciamiento del $1 .^{\circ}$ de septiembre de 2011 la Corte Interamericana estudió si el Estado venezolano había vulnerado los derechos políticos de Leopoldo López Mendoza, por inhabilitarlo por seis años para el ejercicio de funciones públicas: la Corte condenó al Estado por considerar que la sanción de inhabilidad sí desconoció sus derechos políticos, ya que no fue impuesta dentro de un proceso penal y con la intervención de una autoridad judicial. Sin embargo, en el voto concurrente razonado del juez Diego García Sayán se puso de manifiesto que la Convención Americana no podría ser interpretada de una forma estrictamente literal: este juez manifestó que la Convención "no remite a una lista taxativa de posibles causales para la restricción o reglamentación de los derechos políticos" (Corte Interamericana de Derechos Humanos, 2011), y así mismo que el concepto de “"condena, por juez competente, en proceso penal no necesariamente supone que ese sea el único tipo de proceso que puede ser utilizado para imponer una restricción" (Corte Interamericana de Derechos Humanos, 2011).

$12 \mathrm{Al}$ respecto véanse las sentencias C-028 de 2006, SU-712 de 2013 y C-101 de 2018. 
cumpla con todos los estándares de protección al debido proceso y al derecho a la defensa, al tiempo que se protege la moralidad administrativa y los fines esenciales de lucha contra la corrupción ${ }^{13}$.

A continuación procederemos a exponer las características del diseño institucional establecido para el ejercicio de las competencias de revocatoria de inscripción de candidaturas por parte del Consejo Nacional Electoral.

\subsection{Objeto, característica y competencia de la revocatoria}

Con la reforma constitucional de 2009 se atribuyó la competencia al CNE ${ }^{14}$ para decidir la revocatoria de la inscripción de las candidaturas a corporaciones públicas o cargos de elección popular. Según el artículo 108 CP, toda inscripción de candidato inelegible será revocada por esta corporación. La revocatoria procede cuando existe plena prueba de que el candidato está incurso en alguna causal de inhabilidad prevista en la Constitución o la ley, y en tal caso no se podrá declarar su elección, en concordancia con el artículo $265 \mathrm{CP}$.

De acuerdo con lo anterior, la solicitud de revocatoria de la inscripción procede ante la existencia de las causales de inhabilidad taxativamente establecidas en la Constitución o en la ley, según corresponda. No obstante, en el artículo 31 de la Ley 1475 de 2011, estatutaria de los partidos y movimientos políticos, el legislador amplió el objeto de control del instrumento al disponer en el inciso 2. ${ }^{\circ}$ : "Cuando se trate de revocatoria de la inscripción por causas constitucionales o legales, inhabilidad sobreviniente o evidenciada con posterioridad a la inscripción, podrán modificarse las inscripciones hasta un (1) mes antes de la fecha de la correspondiente votación" (resaltado fuera de texto).

En este orden de ideas, la autoridad competente podrá conocer de la revocatoria de la inscripción de un candidato cuando:

i) Se incumplan las condiciones de elegibilidad o requisitos previstos en la Constitución o en la ley para inscribirse como candidato a un cargo de elección popular.

13 RoA RoA, J. La protección de derechos políticos frente a las funciones disciplinarias de las autoridades administrativas: subsidiariedad y deferencia en el Sistema Interamericano de Derechos Humanos. En Revista Brasileira de Políticas Públicas. Brazilian Journal of Public Policy. Vol. 8, n. ${ }^{\circ}$ 2, 2018, 801 ss.

14 Órgano autónomo del poder público, como suprema autoridad de la Organización Electoral regula, inspecciona, vigila y controla el cumplimiento de la actividad electoral y de sus actores, garantizando en plenas condiciones el ejercicio de la participación democrática y de los derechos electorales, para el fortalecimiento del Estado social de derecho. 
ii) Se encuentre incurso en alguna de las causales de inhabilidad contenidas en el artículo $179 \mathrm{CP}^{15}$ para senadores y representantes a la Cámara ${ }^{16}$.

iii) Con posterioridad a la inscripción sobrevenga una causal de inhabilidad, es decir que, con posterioridad al cierre de inscripción de candidaturas, quede en firme una sanción de carácter disciplinario ${ }^{17}$, administrativo o judicial, consistente en destitución e inhabilidad general o suspensión e inhabilidad especial, condena penal consistente en la pena privativa de la libertad o pérdida de investidura.

De acuerdo con la Constitución, para ser elegido senador se requiere "ser colombiano de nacimiento, ciudadano en ejercicio y tener más de treinta años en la fecha de la elección". Por su parte, el artículo 177 señala que para ser elegido representante a la Cámara se requiere ser ciudadano en ejercicio y tener más de 25 años en la fecha de la elección.

El legislador también ha establecido requisitos especiales para quienes aspiren a ser representantes a la Cámara por las circunscripciones especiales, es decir: (i) las comunidades indígenas, (ii) las comunidades afrodescendientes y (iii) los colombianos residentes en el exterior. Estos requisitos habilitantes se encuentran consagrados en la Ley 649 de 2001.

Así, el artículo 2..$^{\circ}$ de la citada Ley 649 dispone: "Los candidatos de las comunidades indígenas que aspiren a ser elegidos a la Cámara de Representantes por esta circunscripción deberán haber ejercido un cargo de autoridad tradicional en su respectiva comunidad o haber sido líder de una organización indígena, calidad que se acreditará mediante certificado de la respectiva organización refrendado por el Ministerio del Interior". Por su parte, el artículo $3 .^{\circ}$ establece que para ser candidato por las comunidades afrodescendientes se requiere ser miembro de la respectiva comunidad y estar avalado previamente por una organización inscrita ante la Dirección de Asuntos de Comunidades Negras del Ministerio del Interior. Por último,

15 Tratándose de candidatos para elecciones territoriales el régimen de inhabilidad se encuentra previsto, principalmente, en la Ley 617 de 2000.

16 Al respecto es importante precisar que la revocatoria puede tener fundamento en cualquiera de las causales de inhabilidad consagradas en la Constitución Política; ni el constituyente ni el legislador establecieron excepción alguna. Sin embargo, es importante recordar que el propósito inicial del Gobierno Nacional era el de habilitar la revocatoria únicamente en los eventos en que el inscrito fuera sancionado disciplinariamente o penalmente; por esta razón y como se verá más adelante, los lineamientos en materia de procedimiento se hicieron pensando solo en el caso de estas dos inhabilidades.

17 De conformidad con lo previsto en el artículo 37 de la Ley 734 de 2002, que establece: "Las inhabilidades sobrevinientes se presentan cuando al quedar en firme la sanción de destitución e inhabilidad general o la de suspensión e inhabilidad especial o cuando se presente el hecho que las generan el sujeto disciplinable sancionado se encuentra ejerciendo cargo o función pública diferente de aquel o aquella en cuyo ejercicio cometió la falta objeto de la sanción. En tal caso, se le comunicará al actual nominador para que proceda en forma inmediata a hacer efectivas sus consecuencias". 
el artículo 5. dispone que los candidatos de los colombianos residentes en el exterior que aspiren a ser elegidos a la Cámara de Representantes deben demostrar ante las autoridades electorales colombianas una residencia mínima de 5 años continuos en el exterior.

El artículo $108 \mathrm{CP}$ otorga la titularidad del derecho de postulación a los partidos y movimientos políticos con personería jurídica reconocida y a los movimientos y grupos significativo de ciudadanos ${ }^{18}$. En el primer evento procede: (i) diligenciar el formulario provisto por la autoridad competente y suscrito por el representante legal del partido o movimiento, o quien el mismo delegue; (ii) que la lista esté integrada por un número inferior o igual al número de curules a proveer, salvo en aquellas circunscripciones electorales en donde se provean dos miembros, caso en el cual podrá estar conformada por tres candidatos; (iii) que la lista esté integrada por mínimo un $30 \%$ de uno de los géneros; (iv) que se consigne la cédula de cada uno de los candidatos de la lista; (v) que exista el aval del partido o movimiento otorgado por el representante legal o por quien este delegue, y (vi) que esté acreditada la aceptación de la candidatura por parte de cada uno de los candidatos de la lista.

Sin embargo, tratándose de inscripciones de movimientos y grupos significativos de ciudadanos será necesario, además de lo anterior, acreditar:

a) La constitución de una póliza de seriedad al momento de efectuar la inscripción, de acuerdo con el monto establecido por el CNE, que en todo caso no podrá exceder del $1 \%$ del fondo que se constituya para financiar a los partidos y movimientos el año correspondiente (art. 9. ${ }^{\circ}$ de la Ley 130 de 1994).

b) Un número de firmas equivalente al $20 \%$ del valor que resulta de dividir el censo electoral por el número de curules a proveer.

c) La creación de un comité integrado por tres ciudadanos, registrado ante la autoridad electoral competente un mes antes del cierre de inscripciones $\mathrm{y}$, en todo caso, registrado antes de iniciar el proceso de recolección de firmas.

Así las cosas, tratándose de la revocatoria de la inscripción de candidaturas nos encontramos frente a un mecanismo de naturaleza administrativa, aspecto que ha sido objeto de reproche en tanto la decisión que adopta el órgano electoral no es definitiva, pues su carácter administrativo permite que el acto

18 En relación con la legitimación para la presentación de las candidaturas, véase Rico Marulanda, C. Las candidaturas independientes en el ordenamiento jurídico colombiano: ¿realidad o ficción? En PAdRón PARdo, F. y CorReA Henao, M. (eds.), ¿El Estado constitucional en jaque? Los retos del componente democrático. Bogotá: Universidad Externado de Colombia, 2018, 143-170. 
pueda ser controvertido ante la jurisdicción de lo contencioso administrativo. Se trata así, más bien, de un instrumento administrativo de control previo de competencia del CNE, que tiene por objeto verificar la correcta confección de las candidaturas, antes de la celebración de la jornada electoral, para salvaguardar el ordenamiento jurídico, especialmente el derecho al sufragio en sus dos dimensiones. El mecanismo permite que los ciudadanos depositen su confianza y su voto en una persona respecto de la cual exista certeza del cumplimiento de las calidades y requisitos de elegibilidad que exige el cargo de senador o representante a la Cámara. Por otro lado, también garantiza que los ciudadanos aspiren en condiciones de igualdad a las candidaturas.

\subsection{Procedimiento y efectos}

La Ley 1475 de 2011 amplió las causales de procedencia de la revocatoria de la inscripción y estableció sus efectos. Sin embargo, guardó silencio en relación con los sujetos legitimados para presentar la solicitud, el procedimiento y los términos para decidir la revocatoria. Con ocasión de esa omisión legislativa absoluta, el CNE, mediante Resolución 0921 de 2011, estableció el procedimiento para que cualquier ciudadano pudiese solicitar la revocatoria del acto de inscripción ${ }^{19}$, y dispuso que esta debe presentarse dentro de los cinco días siguientes al vencimiento del término para hacer modificaciones voluntarias por las causas señaladas en el artículo 31 de la Ley 1475. De acuerdo con este procedimiento, la solicitud se realiza ante los delegados departamentales de la Registraduría Nacional del Estado Civil o directamente ante el CNE, y debe presentarse por escrito señalando: (i) la identificación de quien presenta la solicitud; (ii) la identificación del candidato cuya inscripción se impugna; (iii) el cargo o corporación al cual se haya inscrito la candidatura; (iv) la relación de los hechos y las normas violadas, y (v) las pruebas documentales que respalda la solicitud.

No obstante, el Consejo de Estado ${ }^{20}$ declaró la nulidad de dicha resolución por considerar que la regulación de este mecanismo está sujeta a reserva de ley estatutaria, ya que afecta directamente el ejercicio de derechos fundamentales. Adicionalmente, la corporación expuso que la resolución en examen tenía un contenido que "concierne a las funciones electorales que debe desarrollar la Administración, en este caso la Organización Electoral, respecto de la revocatoria de la inscripción de candidaturas, que como se

19 A diferencia de países como España, en donde únicamente están legitimados para presentar el recurso los candidatos excluidos y los representantes de las candidaturas, tanto de las proclamadas como de aquellas cuya proclamación hubiera sido denegada. Véase Pascua, M. F. El control de las elecciones. Pamplona: Aranzadi, 2009.

20 Consejo de Estado. Sentencia del 6 de mayo de 2013. Rad. 11001-03-28-000-201100068-00. 
expuso, hace parte de la etapa preelectoral del proceso administrativo que culmina con la declaración de la elección".

Luego de declarada la nulidad de la resolución en cita y sin que exista ley que regule la materia producido, el CNE, a partir de mayo de 2013, ha tramitado las solicitudes de revocatoria agotando las etapas del procedimiento administrativo común y principal previstas en el título III del Código de Procedimiento Administrativo y de lo Contencioso Administrativo (CPACA). Se contempla una etapa para que quien pueda resultar afectado con la decisión (candidato inscrito y la agrupación política ${ }^{21}$ ) ejerza su derecho a la defensa y aporte las pruebas que pretenda hacer valer en el proceso.

El proceso de revocatoria de inscripción puede ser iniciado por dos vías: a petición de parte o de oficio. La primera categoría corresponde a los casos en los que los procesos son iniciados mediante solicitud ciudadana. En estos eventos el solicitante debe identificar los candidatos o listas cuya inscripción se pretende revocar; las causas de inhabilidad existentes en cada caso, y las pruebas que sirven como soporte a la solicitud.

Por su parte, los procesos promovidos de oficio son iniciados con fundamento en el artículo 33 de la Ley 1475 de $2011^{[22]}$. El CNE entrega a la Procuraduría General de la Nación el listado de las candidaturas aceptadas, dos días después del vencimiento del término para la modificación e inscripción de listas y candidatos. Tres días después del recibo de esta lista, el órgano de control debe informar al CNE de la existencia de posibles inhabilidades. Lo anterior da lugar al traslado al candidato afectado, para posteriormente finalizar con la expedición de la resolución en la cual se decide o no revocar la candidatura, de conformidad con el acervo probatorio.

Ahora bien, este trámite no responde a las exigencias del proceso electoral, que es "por su naturaleza un procedimiento extremadamente rápido, con plazos perentorios en todas sus fases y tanto en su vertiente administrativa como en los recursos jurisdiccionales que se establecen para el control de la regularidad de todo el proceso" 23 . Se trata de un proceso que no establece

21 La expresión agrupación política en este documento incluye partidos y movimientos políticos con personería jurídica y grupos significativos de ciudadanos.

22 Art. 33: "Divulgación. Dentro de los dos (2) días calendario siguientes al vencimiento del término para la modificación de la inscripción de listas y candidatos, la Registraduría Nacional del Estado Civil y el Consejo Nacional Electoral publicarán en un lugar visible de sus dependencias y en su página en Internet, la relación de candidatos a cargos y corporaciones públicas de elección popular cuyas inscripciones fueron aceptadas. / Dentro del mismo término las remitirá a los organismos competentes para certificar sobre las causales de inhabilidad a fin de que informen al Consejo Nacional Electoral, dentro de los tres (3) días hábiles siguientes a su recibo, acerca de la existencia de candidatos inhabilitados, en especial las remitirá a la Procuraduría General de la Nación para que previa verificación en la base de sanciones e inhabilidades de que trata el artículo 174 del Código Disciplinario Único, publique en su página web el listado de candidatos que registren inhabilidades".

23 PASCUA. El control de las elecciones, cit. 
términos precisos para el desarrollo de las actuaciones y, por lo tanto, otorga un amplio margen de discrecionalidad al CNE. Además, la decisión adoptada no es definitiva, en tanto puede presentarse ante la jurisdicción de lo contencioso administrativo, siempre y cuando el candidato resulte electo.

Finalmente, el efecto principal de la decisión adoptada por el CNE implica la exclusión de las candidaturas que presenten irregularidades. Además, la Ley 1475 de 2011 contempla la posibilidad de que las agrupaciones políticas puedan sustituir la inscripción del candidato revocado, siempre y cuando la decisión se adopte hasta un mes antes de la jornada de votación. En el evento en que la decisión se produzca con posterioridad al término señalado, las agrupaciones pierden la posibilidad de sustituir el candidato. Lo anterior significa que el CNE no pierde la competencia para resolver las solicitudes por fuera del término descrito, tal y como ha ocurrido en varias de las decisiones objeto de estudio ${ }^{24}$; es decir que la competencia de la corporación solo se extingue a partir del día de las elecciones.

En cuanto a las reglas y los parámetros que rigen este procedimiento, el CNE ha señalado que las facultades para declarar la revocatoria se encuentran supeditadas al debido proceso y a la existencia de plena prueba de las causales invocadas. De lo anterior se derivan tres situaciones: (i) la primera referente a que ante la ausencia de un marco normativo que establezca las normas de procedimiento, el CNE debe respetar en todos los casos el debido proceso con las reglas previstas en el CPACA; (ii) la segunda relacionada con la parte accionante, quien tiene una alta carga de diligencia en la recopilación del material probatorio, atendiendo al criterio de existencia de plena prueba; (iii) la tercera consistente en que, a pesar de existir unas reglas de procedimiento, el CNE cuenta con un amplio margen de discrecionalidad al momento de dar trámite y solución a las solicitudes de revocatoria de las candidaturas.

Precisamente en virtud de esa discrecionalidad, el CNE ha desarrollado reglas procedimentales propias en la parte motiva de las resoluciones que resuelven estas solicitudes. Del estudio de estos actos administrativos se observa que estas reglas se reducen a que (i) las irregularidades invocadas como fundamento para iniciar el procedimiento deben ser palmarias o evidentes; (ii) debido a la perentoriedad de los términos y la proximidad a las elecciones, las solicitudes deben ser resueltas de la manera más expedita posible para que los partidos puedan corregir las listas presentadas; (iii) en todos los casos han de respetarse las garantías propias del debido proceso y el derecho de defensa, y (iv) debido a la naturaleza expedita de este procedimiento resultaría imposible adoptar una decisión proveniente de un análisis

24 Esto puede observarse en algunas resoluciones que fueron resueltas con menos de un mes de anterioridad a las elecciones legislativas para el periodo 2018-2022 y realizadas el 10 de marzo de 2018, a saber: 319 del 14 de febrero de 2018, 332 del 14 de febrero de 2018, 320 del 14 de febrero de 2018,334 del 14 de febrero de 2018, 662 del 27 de febrero de 2018. 
jurídico-probatorio exhaustivo, por lo que los medios probatorios deben otorgar la mayor claridad posible respecto de la existencia de las causales de revocatoria ${ }^{25}$.

\section{ANÁLISIS DE LAS SOLICITUDES DE REVOCATORIA DE INSCRIPCIÓN}

DE LAS CANDIDATURAS DE LAS ELECCIONES LEGISLATIVAS 2018-2022

A continuación analizaremos las 106 decisiones adoptadas por el CNE en las cuales se resolvieron las solicitudes de revocatoria de inscripción de candidaturas con fundamento en las causales relacionadas con la ausencia de requisitos y/o de calidades o existencia de inelegibilidades para ser congresista. Este análisis se realizará de acuerdo con cuatro categorías en función del impacto generado en el ejercicio de los derechos políticos y las circunscripciones del sistema electoral colombiano.

\subsection{Las circunscripciones ordinarias ${ }^{26}$}

La mayoría de los procesos iniciados en esta circunscripción se fundaron en la presunta existencia de causales de inhabilidad. De los 59 trámites de revocatoria, en 54 casos se alegó alguna de las causales de inhabilidad; los restantes tenían relación con ausencia de requisitos, falta de aceptación de la candidatura o con temas que escapan de la competencia atribuida al CNE en sede de revocatoria de inscripción.

De la revisión de la totalidad de trámites podemos concluir que el CNE ha construido una línea de decisión en virtud de la cual revoca las candidaturas en caso, en primer lugar, de que exista plena prueba de los supuestos contenidos en la normatividad vigente, en materia de calidades, requisitos y causales de inhabilidad; y en segundo lugar, de que haya ausencia de interpretación probatoria y jurídica por parte de la autoridad electoral. En otras palabras, la revocatoria procede en los casos en que el Consejo se limita a hacer una confrontación objetiva entre los elementos de la disposición y la situación fáctica, esto es, se aplica la consecuencia jurídica como producto de un ejercicio mecánico, que no da lugar a debates jurídicos probatorios ni interpretativos por parte de la corporación.

La anterior situación se justifica, por una parte, en la rapidez que exige el trámite, puesto que la decisión de revocar la inscripción debe permitir a la agrupación política afectada modificar la candidatura. Además, en nuestro criterio, al tratarse de una medida cuyos efectos limitan el ejercicio del derecho al sufragio, la irregularidad debe ser palmaria y ser declarada por un juez. Con mayor razón si se tiene en cuenta que, a la luz de la Convención 
Americana de Derechos Humanos y la interpretación que de ella ha elaborado la Corte Interamericana, las restricciones a este derecho solo pueden ser decretadas por el juez penal ${ }^{27}$.

Lo anterior nos permite sostener que la eficacia del instrumento es mayor en el caso de aquellas causales cuya redacción se presenta en forma de regla jurídica completa, por lo que no son necesarias interpretaciones ni remisiones normativas o jurisprudenciales ${ }^{28}$.

Finalmente, cabe señalar que la línea definida no ha sido aplicada de forma rigurosa. De ser así, el CNE habría tenido que negar todas las solicitudes iniciadas con fundamento en causales distintas a las redactadas en forman de regla jurídica completa. Sin embargo, ni la Constitución ni la ley limitaron la competencia del Consejo a esas causales.

Ejemplo de lo anterior es el caso de la Resolución 258 de 2018, relativa al conocimiento y resolución del proceso en el cual se impugnó la inscripción de Karina Espinosa Oliver como candidata a la Cámara de Representantes por el departamento de Sucre. La solicitud se fundamentó en la relación de parentesco (en segundo grado de consanguinidad) de la candidata con quien para la fecha de la inscripción ocupaba el cargo de viceministro de Relaciones Políticas del Ministerio del Interior, situación que configuraba, aparentemente, la inhabilidad consagrada en el numeral 5 del artículo $179 \mathrm{CP}^{29}$. Inhabilidad cuya configuración requiere de la existencia de los siguientes elementos: (i) vínculo de matrimonio, unión permanente, o parentesco en tercer grado de consanguinidad, primero de afinidad o único civil; (ii) que el vínculo sea con un funcionario que ejerza autoridad civil o política; (iii) que la misma se ejerza en la respectiva circunscripción electoral, y (iv) que el pariente ostente el cargo el día de las elecciones.

En relación con la autoridad civil o política es preciso advertir que no se trata de un concepto unívoco. Este se ha construido con base en las definiciones de la Ley 136 de 1994, en donde la autoridad civil es definida en función de las competencias que se atribuyen y, por su parte, la autoridad

27 Véase supra.

28 De esta misma línea interpretativa es el Consejo de Estado, cuyo presidente se pronunció, en el trámite de aprobación de la reforma constitucional que dio origen a la revocatoria de la inscripción, como se señala a continuación: "Estimamos que esta facultad que en el numeral 10 de la segunda parte del artículo 17 se atribuye al Consejo Nacional Electoral debe restringirse únicamente a los casos de inhabilidad en los que exista sentencia penal condenatoria, o decisión disciplinaria o fiscal debidamente ejecutoriada. / A nuestro juicio, extender la competencia para revocar la inscripción del candidato y para negar declarar una elección a todas las causales de inhabilidad, puede llegar a afectar el debido proceso frente a aquellas situaciones inhabilitantes que, en la mayoría de los casos, requieren análisis con grado de complejidad no obstante que en principio se les considere acreditadas con plena prueba".

29 Art. 179: "No podrá ser congresista: [...] 5. Quienes tengan vínculos por matrimonio, o unión permanente, $\mathrm{o}$ de parentesco en tercer grado de consanguinidad, primero de afinidad y único civil, con funcionarios que ejerzan autoridad civil o política". 
política se define como aquella que tiene el alcalde como jefe del municipio, y se enumeran los cargos municipales que son autoridad política.

Teniendo en cuenta lo anterior, están expresamente definidos los cargos que tienen autoridad civil y política en el municipio. Sin embargo, no hay una definición para el departamento o la nación. Para estos casos se han aplicado por analogía aquellos que implican ejercicio de autoridad civil y política en el municipio. La aplicación de estas normas no resulta suficiente para determinar si un cargo distinto de los que hacen parte del gobierno departamental y nacional es o no autoridad política.

En lo que se refiere al ámbito temporal para determinar cuándo se configura la inhabilidad, hasta el año 2015 la línea jurisprudencial de la Sección Quinta del Consejo de Estado había sido clara y establecía que para la configuración de la inhabilidad era necesario que el ejercicio de autoridad tuviera lugar el día de la elección. A partir del año 2015 la jurisprudencia varió y, mediante sentencia de unificación el Consejo de Estado, señaló que la causal de inelegibilidad no se configura hasta un día antes de la inscripción de la candidatura, y que tendría aplicación a partir de las elecciones de $2018^{[30]}$.

Ahora bien, en el caso de la revocatoria que estamos analizando, el cargo que se cuestiona es el de viceministro, el cual no hace parte del gobierno municipal y, por tanto, no encaja en la definición de autoridad política de la Ley 136 de 1994. Tampoco tiene atribuciones nominadoras y sancionatorias, y esto lo excluye del ejercicio de autoridad civil, por lo menos a simple vista.

Así las cosas, la decisión de revocar la inscripción de la candidatura de Karina Espinosa Oliver obligó al CNE a realizar una labor interpretativa para determinar si el cargo de viceministro incluye el ejercicio de autoridad, civil o política. Por ello acudió a confrontar la Constitución, la Ley 489 de 1998, el manual de funciones contenido en la Resolución 0322 de 2015 y la jurisprudencia administrativa, desconociendo con lo anterior la prohibición de hacer interpretaciones jurídicas establecida por la misma corporación, asî como la prohibición de aplicar la analogía.

Por otro lado, resaltamos las 41 solicitudes que tuvieron origen en la existencia de la causa de inhabilidad contenida en el numeral 1 del artículo $179 \mathrm{CP}$, que establece que no pueden ser congresistas quienes hayan sido condenados por sentencia judicial a pena privativa de la libertad, excepto por delitos políticos o culposos.

Se trata de una causal de inhabilidad que se configura con ocasión del ejercicio de la potestad sancionatoria del Estado, la cual exige que: (i) quien aspire a ser congresista haya sido condenado penalmente; (ii) la condena sea consecuencia de la comisión de cualquier delito, salvo que sea de carácter político o culposo; (iii) la conducta haya sido sancionada con pena privativa

30 Consejo de Estado, Sección Quinta. Sentencia del 26 de marzo de 2015. M.P.: Alberto Yepes. Rad. 11001-03-28-000-2014-00034-00. 
de la libertad, y (iv) la condena haya sido impuesta en cualquier época, incluso antes de la entrada en vigencia de la Constitución de 1991.

Dentro de este grupo de procesos se destacan $15^{[31]}$ que dieron lugar a la revocatoria de la inscripción de la candidatura, obligando a las organizaciones políticas a reemplazar el candidato respecto del cual se configuró la causal de inhabilidad. Estos se iniciaron con fundamento en el traslado que hace el CNE a la Procuraduría General de la Nación por mandato del artículo 33 de la Ley 1475 de 2011.

De la lectura de las resoluciones se evidencia que la decisión de revocar la inscripción de las candidaturas surge de la confrontación de la situación fáctica, acreditada con la certificación de antecedentes de la Procuraduría General de la Nación, con los supuestos previstos por la disposición constitucional para su configuración. Lo anterior nos permite concluir que: (i) la certificación de antecedentes disciplinarios expedida por la Procuraduría constituye el medio probatorio idóneo y suficiente para acreditar la existencia de una condena judicial vigente, en los términos de la disposición constitucional ${ }^{32}$, y (ii) la eficacia del instrumento de control es mayor cuando inicia en el traslado al que venimos haciendo referencia, en tanto fue allí en donde se identificaron la totalidad de los procesos, por esta causal llamados a prosperar.

Sin embargo, si se tiene como único medio probatorio la información institucional de la Procuraduría (SIRI), solo es posible identificar aquellas causales de inhabilidad que tienen origen en la potestad sancionatoria del Estado, es decir, las derivadas de procesos penales, de pérdida de investidura, disciplinarios, fiscales, entre otros.

Teniendo en cuenta lo anterior, podemos concluir que en estos eventos las organizaciones políticas faltan a su deber de diligencia. Es de tenerse en cuenta que una simple búsqueda en los repositorios de información institucionales les permitiría identificar la existencia de precandidatos inhabilitados y con ello evitar afectar sus listas. Así las cosas, es claro que 12 revocatorias de

31 Estos casos fueron decididos mediante las resoluciones: 159 del 6 de febrero de 2018 de 2018; 217 del 8 de febrero de 2018; 171 del 6 de febrero de 2018; 210 del 8 de febrero de 2018; 179 del 8 de febrero de 2018; 211 del 8 de febrero de 2018; 223 del 8 de febrero de 2018; 150 del 6 de febrero de 2018; 173 del 6 de febrero de 2018; 142 del 6 de febrero de 2018; 227 del 8 de febrero de 2018; 163 del 6 de febrero de 2018; 228 del 8 de febrero de 2018, y 319 del 14 de febrero de 2018. Los detalles de estas resoluciones pueden ser consultados infra en el Anexo. Tabla 1.8.1.

32 Al respecto, el Consejo de Estado señaló: "En este orden de ideas, es claro que la certificación de antecedentes disciplinarios constituye medio probatorio suficiente y apto jurídicamente para demostrar la existencia de inhabilidades especiales aplicadas al respectivo cargo en cabeza de los candidatos que fueron reportados en el listado que envió la Presidente de la Comisión Nacional de Control y Asuntos Electorales de la Procuraduría General de la Nación, y en consecuencia el Consejo Nacional Electoral revocará toda inscripción de los candidatos sujetos". Consejo de Estado. Sentencia del 20 de septiembre de 2007. Rad. 25000-23-25-0002004-05226-01(0864-07). 
candidaturas por esta causal en la circunscripción ordinaria son un indicador de la falencia en los controles de las directivas de las organizaciones a la hora de confeccionar sus listas. Esta situación es aprovechada por las organizaciones políticas en su propio favor y en detrimento de la sana competencia electoral.

Sin embargo, al hacer una revisión de cuáles fueron las organizaciones políticas a las cuales se les revocó la inscripción de sus candidatos se advierte que el mayor número recayó sobre organizaciones coyunturales creadas para la época electoral -como es el caso del Movimiento Todos Somos Colombia-, carentes de una estructura robusta. Aunque se registran casos de partidos tradicionales -como el Liberal-o con organizaciones robustas -como Cambio Radical-, el número es muy inferior. Lo anterior permite concluir que las organizaciones políticas con una fuerte infraestructura, organizada, y con directivas con experiencia, es una garantía de menores fallas en los controles ${ }^{33}$.

Para recapitular, en la circunscripción ordinaria prosperaron 14 solicitudes de revocatoria de la inscripción de candidaturas, 12 por la existencia de plena prueba de la condena judicial; 1 por la relación de parentesco con persona que ejercía autoridad civil o política, y 1 por la celebración de contratos con el Estado.

El diseño de la revocatoria no castiga a la organización política, por el contrario, le otorga la facultad de inscribir a otro candidato, siempre y cuando la revocatoria se decida a más tardar a un mes de la celebración de las elecciones. Este diseño no se compagina con la apuesta de las reformas de la representación política introducidas desde el año 2003, reformas que apuntan a un sistema electoral que privilegia las organizaciones fuertes, con una marcada organización democrática interna, y que sanciona a aquellas que no cumplen con los principios de transparencia, diligencia y probidad, entre otros.

La redacción de las causales, general y ambigua, es utilizada por las organizaciones para su beneficio electoral, en desmedro del interés general y del ejercicio de los derechos políticos. Esto da lugar a un desequilibrio en las relaciones entre las organizaciones políticas, generando ventajas para algunas a la hora de la competencia electoral.

Es así como la relación de un candidato con una persona que ejerza autoridad civil y política en la jurisdicción en la que se postula ha sido utilizada en favor de las organizaciones y en desmedro del equilibrio de las listas de

33 En la circunscripción ordinaria, la falla en los controles es un común denominador de las siguientes organizaciones políticas a las que se les revocó la inscripción de sus candidatos: Partido Cambio Radical (1 revocatoria), Movimiento político Todos Somos Colombia (7 revocatorias), Partido Alianza Social Independiente (ASI) (1 revocatoria), Partido Somos (2 revocatorias), Partido Liberal Colombiano (1 revocatoria). Ahora bien, en la circunscripción especial de comunidades afrodescendientes también se les revocó la inscripción a Asociación Colombiana Negras Huellas de Africanía en Paz (1 revocatoria), Fundación Afrodescendiente Profesional de Córdoba (1 revocatoria) y Consejo Comunitario de la Comunidad Negra de Limones (1 revocatoria). 
candidatos que se presentan a las elecciones. El hecho es que una lista que tenga un candidato con una relación de parentesco con una autoridad está en mejores condiciones o en situación privilegiada. La organización política se aprovecha de esa ambigüedad y prefiere incluir en su lista al candidato, pues con ello tiene una ventaja en la competencia electoral, como ocurrió en el caso del Partido Liberal en el departamento de Sucre, como ya se expuso.

Adicional a lo anterior, si la candidatura en mención no hubiera sido objeto de la solicitud ante el CNE, no se habría revocada, pudiendo ser elegida la candidata con la prerrogativa de tener un parentesco con una autoridad en la respectiva circunscripción. E incluso, si llegara a declararse la nulidad de la decisión por el Consejo de Estado, la organización seguiría teniendo la prerrogativa de haber contado con unos votos de un candidato que tenía una mejor posición que los demás, lo que podría haber contribuido a una mayor votación de la lista de la organización política respectiva.

Situación similar puede presentarse en los casos de celebración de contratos. La ambigüedad sobre quién es representante legal, si se pueden delegar estas competencias, o cuál es el régimen jurídico aplicable para poder constituir o no inhabilidad, es utilizada por la organización para obtener una mejor posición en la competencia electoral, como se resalta en el caso de Antanas Mockus. Pues un candidato que haya tenido una relación con una entidad pública es un candidato en una mejor posición en la competencia electoral.

Lo anterior pone de presente que existe una zona gris aprovechada por las organizaciones políticas, que se explica por: (i) la forma indeterminada y abierta en que han sido redactada las causales de inhabilidad, respecto de las cuales existe una obligación del constituyente de precisión y certeza, en tanto se trata de limitaciones al ejercicio del derecho fundamental a ser elegido, y (ii) el criterio del operador jurídico y sus intereses políticos. Si bien no es objeto de análisis de este escrito, no podemos desconocer el origen y la forma de elección de los magistrados del CNE, quienes son postulados por las organizaciones políticas con presencia mayoritaria en el Congreso de la República y elegidos por este mismo órgano.

Por último, debe tenerse en cuenta que la existencia de un régimen de responsabilidad en cabeza de las organizaciones y directivos por el hecho de avalar candidatos electos que resulten inhabilitados parece no ser un elemento disuasorio suficiente. En últimas, estos prefieren asumir las consecuencias sancionatorias de un proceso administrativo, frente los réditos electorales que les genera la postulación de determinadas figuras políticas. Lo anterior teniendo en cuenta que la posible declaratoria de nulidad electoral con fundamento en una causal de inelegibilidad afecta únicamente al candidato y no a la organización; es decir que los votos depositados a su favor cuentan a efectos de determinar el número de curules del partido o movimiento, a pesar de la nulidad electoral. 


\subsection{La circunscripción especial de las comunidades afrodescendientes ${ }^{34}$}

Dentro de este grupo encontramos un total de 34 trámites de revocatoria, de las cuales prosperaron 17 solicitudes. Las causales invocadas correspondieron a la existencia de inhabilidad y al incumplimiento de los requisitos establecidos para la inscripción de candidatos por las circunscripciones especiales, en los términos de la Ley 649 de 2001. En estos casos, el cNE estableció la necesidad de acreditar de manera concomitante e inescindible: (i) la pertenencia a la comunidad y (ii) el contar con el aval de una organización -consejo comunitario- previamente inscrita ante la Dirección de Asuntos de Comunidades Afrodescendientes del Ministerio del Interior.

En los procesos en los que se revocaron las candidaturas, el CNE determinó que no se cumplían las exigencias contenidas en el artículo $3 .^{\circ}$ de la Ley 649 de 2001 para adelantar la inscripción de candidatos por la circunscripción especial para las comunidades afrodescendientes ${ }^{35}$. Se trata de eventos en los cuales los candidatos no obtuvieron el aval por parte de consejos comunitarios, organizaciones estas encargadas de la administración interna, el ejercicio de derechos y la representación legal de las comunidades. En tales casos el aval fue otorgado por organizaciones de base, las cuales no responden a la lógica y características de los consejos comunitarios y, por lo tanto, no cuentan con legitimidad para postular candidatos por la circunscripción especial.

En los procesos en los cuales se negó la revocatoria de las candidaturas ${ }^{36}$, el CNE también decidió con base en el criterio de existencia de plena prueba para establecer el cumplimiento de los requisitos establecidos en los artículos $2 .^{\circ}$ y $3 .^{\circ}$ de la Ley 649 de 2001 (que se trate de miembros de la respectiva comunidad y que hayan sido avalados previamente por una organización inscrita en el Ministerio del Interior). Adicionalmente, la corporación reiteró en estos casos que las comunidades afrodescendientes tenían plena autonomía para determinar quiénes hacían parte de ellas y qué personas eran las adecuadas para recibir el aval.

34 Véase Anexo. Tabla 1.8.2.

35 Las pruebas para resolver estos casos fueron obtenidas por conducto de la Dirección de Asuntos para las Comunidades Negras del Ministerio del Interior, a partir de la revisión de las bases de datos del Registro Único de Organizaciones de Base y Consejos Comunitarios. La corporación reiteró que estos requisitos deben ser cumplidos de manera concomitante e inescindible, so pena de que se configure una irregularidad que permita la prosperidad de la solicitud de revocatoria de la respectiva candidatura.

36 Estos procesos fueron resueltos mediante las resoluciones: 220 del 8 de febrero de 2018; 239 del 8 de febrero de 2018; 321 del 14 de febrero de 2018; 333 del 14 de febrero de 2018; 400 del 21 de febrero de 2018, 401 del 21 de febrero de 2018; 402 del 21 de febrero de 2018; 404 del 21 de febrero de 2018; 405 del 21 de febrero de 2018; 409 del 21 de febrero de 2018; 411 del 21 de febrero de 2018; 416 del 22 de febrero de 2018; 663 del 27 de febrero de 2018; 664 del 27 de febrero de 2018. 
De los 34 trámites, 31 solicitudes de revocatoria fueron promovidas por la misma persona, Gustavo Adolfo Prado Cardona. De acuerdo con la información del sitio web congresovisible.org ${ }^{37}$, esta persona fue congresista y militante del Consejo Comunitario de los Corregimientos de San Antonio y el Castillo de Valle del Cauca, al cual pertenece desde el 13 de febrero de 2014. Esta situación puede indicar la posibilidad de que el accionante buscara revocar las candidaturas de sus potenciales competidores en la circunscripción especial, ya fuera para llegar al Congreso de la República o para que su consejo comunitario obtuviese representación dentro del órgano legislativo en detrimento de las demás organizaciones de este tipo.

También llama la atención el hecho de que parecería existir contradicción entre las afirmaciones sobre la autonomía de las comunidades afrodescendientes para elegir quién hace parte de ellas y la exigencia de plena prueba para demostrar la situación de no pertenencia. De concurrir plena seguridad respecto del primer argumento, no se debería alegar el incumplimiento de la carga probatoria en cabeza del solicitante para negar la revocatoria de inscripción de las candidaturas.

Si estas comunidades tienen la libertad de selección de sus miembros -la cual es un derecho en virtud de su autonomía- no sería procedente el análisis posterior de la situación de ausencia de prueba sobre dicha pertenencia, ya que con la constatación de la primera situación se tendría por probado el requisito del vínculo de pertenencia. Así las cosas, no habría necesidad de negar la revocatoria de las candidaturas bajo el entendido de que la parte actora no ha cumplido con la carga de probar los supuestos de hecho que alega, siendo más estrictos al momento de decidir.

Por último, la creación de unas curules para las comunidades afrodescendientes con el objetivo de lograr su inclusión en los circuitos de la representación política, en el discurso nacional y en el diseño de las políticas públicas no se ha logrado. Lo anterior por cuanto no existe una reglamentación clara sobre qué debe entenderse como perteneciente a dichas comunidades. ¿ $\mathrm{Ne}$ cesariamente debe ser una persona negra?, $¿$ o puede una persona de otra raza agenciar los intereses de la comunidad, siempre y cuando cuente con el aval de la organización? Estas ambigüedades han ocasionado muchos problemas respecto de la legitimidad de los candidatos elegidos en las elecciones para el periodo 2018-2022, y generó la declaratoria de la nulidad de las elecciones para el periodo 2014-2018 $8^{[38]}$.

37 Véase: http://congresovisible.org/congresistas/perfil/gustavo-adolfo-prado/8688/ (consultado el 8 de octubre de 2018),

38 Para las elecciones del periodo 2018-2022, sobre la falta de legitimidad de los elegidos por las circunscripciones afrodescendientes véase: https://lasillavacia.com/silla-pacifico/ estos-son-los-dos-representantes-por-las-curules-afros-65184 Y para las elecciones del periodo 2014-2018 en las que se declaró la nulidad de la elección por el Consejo de Estado véase: https:// 
Adicional a lo anterior, existe una explosión de organizaciones en las que cada una puede avalar candidatos, y esto hace muy tediosa la elección y la competencia electoral ${ }^{39}$. Sin embargo, el análisis de dicha cuestión desborda el contenido del presente documento.

\subsection{La circunscripción especial indígena ${ }^{40}$}

El CNE resolvió dos solicitudes de revocatoria en relación con la circunscripción especial indígena, la primera de ellas correspondiente a la inscripción de la candidatura de un ciudadano avalado por el Movimiento Alternativo Indígena y Social "MAIS". De acuerdo con la accionante, el candidato se encontraba inhabilitado por haber sido condenado a una pena de seis latigazos por parte de su comunidad indígena, al ser hallado responsable por la conducción de un vehículo automotor en estado de embriaguez. El solicitante señaló que dicha conducta es sancionable con pena privativa de la libertad de acuerdo con las normas del Código Penal, por lo que, haciendo la analogía con el caso concreto, se configuraba la causal de inhabilidad del numeral 1 del artículo $179 \mathrm{CP}$.

El CNE negó la solicitud de revocatoria debido a que no existía plena prueba de dicha inhabilidad. El demandado no se encontraba reportado como inhabilitado ni presentaba antecedentes penales o disciplinarios según las pruebas aportadas por la Procuraduría General de la Nación. Atendiendo a la naturaleza taxativa de las inhabilidades y a su rango constitucional, las causales de inhabilidad no pueden ser objeto de homologación y resulta necesario que contra el candidato pese una sentencia judicial debidamente ejecutoriada. Por último, la comunidad indígena a la cual pertenece el candidato aclaró que no existían sanciones en contra suya y que ellos no eran competentes para determinar la existencia de inhabilidades para inscribir candidatos.

Ante esta clase de situaciones no es posible establecer equivalencias entre las penas impuestas por las comunidades indígenas y aquellas impuestas por la jurisdicción ordinaria. Si bien puede ocurrir que se presenten conductas que sean punibles en ambas jurisdicciones, la existencia del fuero indígena provoca que las comunidades asuman la competencia para juzgar y sancionar estas conductas, en el marco de su autonomía ${ }^{41}$. Lo anterior sustrae la potestad punitiva del Estado en favor de los derechos de las comunidades indígenas,

www.semana.com/nacion/articulo/consejo-de-estado-eleccion-de-congresista-afro-moisesorozco/481849 (consultadas el 11 de julio de 2019).

39 De acuerdo con la Dirección de Asuntos para las Comunidades Negras, Afrocolombianas, Raizales y Palenqueras del Ministerio del Interior existen 926 registros que comprenden a las organizaciones y a los consejos. Véase: http://sidacn.mininterior.gov.co/DACN/Consultas/Co nsultaCertificadosOrgConsejoPublic?grid-page=1 (consultado el 11 de julio de 2019).

40 Véase Anexo. Tabla 1.8.3.

41 Corte Constitucional. Sentencia T-642 de 2014. 
en reconocimiento de lo establecido por la Declaración Universal de las Naciones Unidas sobre los Derechos de los Pueblos Indígenas en materia de aplicación de procedimientos, prácticas y sistemas jurídicos para mantener el orden de sus instituciones.

Al ser titulares de derechos políticos, estas comunidades tienen la posibilidad de participar en la conformación y ejercicio del poder público desde sus instituciones propias y de acuerdo con sus valores, usos y costumbres. De igual forma, tienen la prerrogativa de impartir justicia según su cosmovisión, por lo que la finalidad de sus medidas represivas puede ser distinta de la buscada por las sanciones impuestas por la jurisdicción ordinaria. Es asî como en las comunidades indígenas las penas o castigos son asumidos como medidas de carácter espiritual, una forma de restaurar las cosas al estado anterior a la ocurrencia de la transgresión a sus reglas básicas, de forma que se restablezca la armonía en la comunidad ${ }^{42}$.

Estas circunstancias especiales impiden hablar de homologación entre supuestos de hecho que generen inhabilidades para los candidatos indígenas. En estos casos el funcionamiento del mecanismo de revocatoria se circunscribe a la existencia de sentencias debidamente ejecutoriadas por la comisión de delitos que impongan pena privativa de la libertad. En consonancia con lo anterior, si bien no está radicada en cabeza de las comunidades indígenas la facultad de establecer la existencia de inhabilidades para avalar a sus representantes, las mismas no escapan del deber de diligencia que se impone a las organizaciones políticas de verificar que sus candidatos no estén inmersos en causales de inelegibilidad. Por lo que, de presentarse estos supuestos de hecho, será procedente la revocatoria de las respectivas candidaturas.

Por otro lado, en el proceso resuelto por el CNE mediante la Resolución 165 del 6 de febrero de 2018 se solicitó la revocatoria de inscripción de las candidaturas presentadas por los partidos Alianza Social Indígena, Autoridades Indígenas de Colombia y Movimiento Alternativo Indígena y Social en la circunscripción ordinaria, bajo el argumento de que estos partidos no podían postular candidatos en las circunscripciones ordinaria e indígena de manera simultánea. Señalaron los solicitantes que el crecimiento que han tenido estas organizaciones en las elecciones legislativas los equipara con los partidos con personería jurídica que avalan candidatos por la circunscripción ordinaria. Razón por la cual deben ser tratadas igual que las demás organizaciones políticas. El CNE negó la solicitud con fundamento en la inexistencia de una norma que impida a los partidos o movimientos políticos indígenas presentar listas en la circunscripción ordinaria.

42 Peña Jumpa, A. Multiculturalidad y Constitución: el caso de la Justicia Comunal Aguaruna en el Alto Marañón. Lima: Centro de Estudios Constitucionales, 2009, 83. 
Al respecto, la Sección Quinta del Consejo de Estado, en sentencia de $2015^{[43]}$, señaló que la presentación de listas de forma simultánea al Senado, tanto para la circunscripción ordinaria como para la especial, no constituye una causal de revocatoria de las candidaturas. La corporación manifestó que no existe una norma que prohíba esta situación y que, de existir, la misma sería discriminatoria. Lo anterior fue reiterado en sentencia del 14 de mayo de $2015^{[44]}$, en la cual la Sección Quinta estableció: (i) que no existe una norma que prohíba la inscripción de listas de forma simultánea por parte de las organizaciones políticas que representan a las minorías étnicas; (ii) que una prohibición en este sentido constituiría una medida discriminatoria contra estos partidos y limitaría sus derechos políticos, y (iii) que la condición de minorías étnicas no limita el derecho de participar en el ejercicio y conformación del poder público.

Esta postura jurisprudencial está enmarcada en el reconocimiento de una acción afirmativa a favor de las comunidades indígenas, que promueve la generación de espacios de representación política. La acción afirmativa contempla la posibilidad de presentar varias listas de candidatos, una en la circunscripción ordinaria y otra en la indígena.

Sin embargo, esto impone tener en cuenta las siguientes tres reflexiones: (i) si en verdad se ha logrado una mayor y mejor representación de estas comunidades; (ii) si las medidas afirmativas han sido usadas por candidatos que no tienen ningún vínculo con los indígenas, y (iii) si, en el peor de los casos, las medidas no tienen como objetivo incorporar las necesidades de estas comunidades en el discurso público nacional

Las reglas electorales que persiguen una mayor participación de las comunidades indígenas en los asuntos públicos imponen la necesidad de coordinación entre las autoridades nacionales y las indígenas para efectos de definir si las sanciones que han impuesto las comunidades encajan en el concepto de inhabilidad, y cuál es la real representación de los intereses de las comunidades en las candidaturas en la circunscripción ordinaria y en la especial.

\subsection{Las curules de las FARC reconocidas en el Acto Legislativo 03 de 2017 $7^{[45]}$}

Se trata de 11 trámites, de los cuales 5 iniciaron por el cruce de información con la plataforma sIRI y los otros 6 fueron iniciados a solicitud de parte ${ }^{46}$ en

43 Consejo de Estado, Sala de lo Contencioso Administrativo, Sección Quinta. Sentencia del 26 de febrero de 2015. M.P.: Alberto Yepes Barreiro. Rad. 11001-03-28-000-2014-00115-00.

44 Consejo de Estado, Sala de lo Contencioso Administrativo, Sección Quinta. C.P.: Susana Buitrago Valencia. Sentencia del 14 de mayo de 2015. Rad. 11001-03-28-000-2014-00104-00.

45 Véase Anexo. Tabla 1.8.4.

46 Estos procesos fueron iniciados a raíz de las solicitudes presentadas por el candidato y actual representante a la Cámara José Jaime Uscátegui Pastrana, miembro del partido político 
contra de los candidatos inscritos por el partido político Fuerza Alternativa Revolucionaria del Común - FARC, partido creado por las antiguas Fuerzas Armadas Revolucionarias de Colombia - FARC-EP luego de su reincorporación a la vida civil, en virtud del Acuerdo Final de Paz suscrito con el Gobierno de Colombia.

En estos casos se argumentó que los candidatos eran autores de delitos graves, violaciones a los derechos humanos e infracciones al derecho internacional humanitario. El CNE sostuvo que dentro de los argumentos esgrimidos en las solicitudes no se había invocado ninguna causal de las taxativamente señaladas por el ordenamiento jurídico y puso de presente que, aunque quedó demostrado que contra los candidatos se habían emitido órdenes de captura, e incluso contra algunos existían procesos penales vigentes, al no existir sentencias judiciales condenatorias en firme no se configuraban las inhabilidades alegadas.

Llama la atención que el CNE adoptara estas decisiones reconociendo la fuerza jurídica vinculante del Acuerdo Final de Paz firmado entre el Gobierno de Colombia y las FARC-EP. La corporación reiteró el deber de dar cumplimiento de buena fe a las obligaciones adquiridas en virtud del Acuerdo de Paz, de acuerdo con lo establecido con los actos legislativos 02 y 03 de 2017. Vale la pena mencionar asimismo que el CNE encontró probado que en dos de estos casos los candidatos se encontraban incursos en la causal de inhabilidad del artículo 179 numeral $1 \mathrm{CP}$, pero que dichas condenas se encontraban suspendidas en virtud de los compromisos suscritos con el Acuerdo de $\mathrm{Paz}^{47}$. Por otro lado, en los cuatro casos restantes ${ }^{48}$, la corporación concluyó que se trataba de casos en los cuales solo existían órdenes de captura en contra de los candidatos, situación que enervaba la configuración de la causal de inhabilidad propuesta.

Con estas decisiones el CNE interpretó de manera adecuada el artículo 122 $\mathrm{CP}$, disposición que establece, por un lado, la regla general de que no pueden ser inscritos como candidatos a cargos de elección popular, ni ser elegidos, ni designados como servidores públicos, quienes hayan sido condenados en cualquier momento por sentencia penal a pena privativa de la libertad; y por otro lado, la excepción que dispone que quienes hagan parte de grupos armados al margen de la ley, suscriban un acuerdo de paz y abandonen la lucha armada pueden tener la oportunidad de reintegrarse a la vida civil y

Centro Democrático e hijo del general Jaime Uscátegui, condenado por su participación en la masacre de Mapiripán, Meta, cometida entre el 15 y el 20 de julio de 1997.

47 Se trata de los procesos resueltos mediante las resoluciones 252 del 8 de febrero de 2018 y 254 del 8 de febrero de 2018.

48 Resueltos mediante las resoluciones 225 del 8 de febrero de 2018, 247 del 8 de febrero de 2018, 253 del 8 de febrero de 2018 y 322 del 14 de febrero de 2018. 
participar en la conformación del poder público como candidatos a corporaciones de elección popular.

\section{ACCIONES DE NULIDAD ELECTORAL PROMOVIDAS \\ EN LAS ELECCIONES LEGISLATIVAS 2018-2022}

Es preciso poner de presente que Colombia tiene un modelo mixto de justicia electoral, que contempla mecanismos de control de los actos electorales de naturaleza administrativa y judicial que además son previos y posteriores, respectivamente. Por una parte, (i) la revocatoria de inscripción de las candidaturas, la cual ha sido explicada a lo largo de este documento, y (ii) las reclamaciones electorales, que tienen lugar en sede de escrutinio y cuyo conocimiento ha sido atribuido a las autoridades electorales, es decir, las comisiones escrutadoras y el CNE. Por otra parte, la acción de nulidad electoral, mecanismo posterior de control judicial de conocimiento exclusivo de la jurisdicción contencioso-administrativa. Se trata de una acción pública que tiene como finalidad realizar un adecuado control de legalidad del acto administrativo por medio del cual se declara la elección y revestir de seguridad jurídica la elección.

En este epígrafe haremos un breve análisis de lo que ha ocurrido hasta la fecha con los procesos de nulidad electoral iniciados con ocasión de la declaratoria de la elección de los miembros del Congreso de la República para el periodo 2018-2022, con el propósito de identificar, en primer lugar, si existen coincidencias entre estos procesos y los trámites de revocatoria de candidaturas que nos permitan evidenciar posiciones contrarias, si hay lugar a ello, y analizar las características del medio de control en función de la garantía del derecho al sufragio; y, en segundo lugar, si existe una línea de comportamiento por parte de las organizaciones políticas en relación con el deber que les asiste de presentar candidaturas pulcras.

Ahora bien, como consecuencia de las elecciones legislativas para el período 2018-2022 se interpusieron 107 demandas en ejercicio del medio de control de nulidad electoral, ante la Sección Quinta del Consejo de Estado. Dentro de este conjunto de acciones, 61 se fundaron en la existencia de causales objetivas, mientras que en 46 oportunidades se alegó la configuración de causales subjetivas ${ }^{49}$ para solicitar la anulación de los actos de elección. En el último caso, de las 46 demandas, 9 fueron objeto de acumulación en 4 expedientes, para un total de 33 procesos.

49 Las causales objetivas, entendidas como circunstancias que afectan el proceso de votación y escrutinio, se encuentran contenidas en los numerales 1, 2, 3, 4, 6 y 7 del artículo 275 de la Ley 1437 de 2011, que contempla las causales de anulación electoral. Por su parte, las causales subjetivas están desarrolladas en los numerales 5 y 8 de la misma disposición, las cuales recaen sobre el candidato y se refieren a condiciones de elegibilidad e inhabilidad del candidato. 
En consonancia con el análisis realizado respecto de los procesos de revocatoria de inscripción de candidaturas adelantados por el CNE, debe resaltarse que dentro de los 46 procesos de nulidad electoral encontramos cuatro coincidencias, las cuales corresponden a la revisión de las candidaturas y la posterior declaratoria de la elección de Horacio José Serpa y Feliciano Valencia, senadores de la República por la circunscripción nacional e indígena, respectivamente; y de César Augusto Lorduy y Antonio José Sanguino, representantes a la Cámara por los departamentos del Atlántico y Cundinamarca, respectivamente.

En el caso de los procesos presentados en contra de Horacio José Serpa, César Augusto Lorduy y Antonio José Sanguino, el debate jurídico y probatorio se concentró en la eventual existencia de la indebida confección de las candidaturas por no reunir los requisitos (falta de competencia en el otorgamiento del aval) o por encontrarse incursos en alguna de las causales de inhabilidad. Específicamente se estudiaron las causales sobre ejercicio previo de autoridad política por parte de los candidatos, coincidencia de períodos del elegido a cargos o corporaciones cuyo período coincida en el tiempo, y celebración de contratos con el Estado durante el término de la prohibición.

En estos eventos, el CNE soportó sus decisiones en la ausencia de plena prueba que permitiera acreditar la configuración de cada uno de los elementos que dan lugar a la existencia de la inelegibilidad alegada. La decisión de los casos no implicó por parte de la corporación debate jurídico alguno, y mucho menos derivó en aplicaciones analógicas, y en todos los casos se negó la solicitud de revocatoria de las inscripciones. En el mismo sentido se pronunció la Sección Quinta del Consejo de Estado, que se abstuvo de declarar la nulidad de los actos administrativos por medio de los cuales se declaró la elección de los senadores y de los representantes a la Cámara citados.

Ahora bien, no podría ser de otra forma si tenemos en cuenta que el ejercicio desplegado por el CNE consistió en la remisión constante a la jurisprudencia del máximo órgano de la jurisdicción contencioso-administrativa en la cual se ha fijado la línea interpretativa de algunas causales de inhabilidad, en especial de aquellas en las cuales de su lectura gramatical no surge un sentido normativo unívoco, claro y preciso. Así, la ambigüedad que presentan da lugar a que se puedan derivar distintas interpretaciones, obligando a la autoridad judicial a fijar la interpretación que en mayor medida permita el ejercicio del derecho fundamental respectivo, en este caso el derecho al sufragio pasivo.

Sin embargo, no cabe duda de que la identificación y aplicación de la decisión judicial que se ajusta a las condiciones de hecho y de derecho de un caso concreto requiere del análisis del operador jurídico. Análisis que va más allá de un simple ejercicio mecánico de subsunción de la situación fáctica en el enunciado normativo. Esto permite que la autoridad administrativa tenga un margen de discrecionalidad amplio, debiéndosele adicionar el componente 
político en razón al origen y forma de elección de los magistrados del CNE, que ya hemos mencionado.

La discrecionalidad en mención puede ser limitada por la jurisdicción contencioso-administrativa en aquellos casos en que el CNE no revoca la candidatura impugnada y el candidato resulta elegido. En estos casos el acto que declara la elección puede ser impugnado con posterioridad, a través de la acción de nulidad electoral, facilitando la corrección de los defectos a que haya lugar y que sean imputables a la autoridad administrativa.

Lo anterior significa que escapan de la órbita de control de la jurisdicción por medio de este mecanismo las decisiones de la organización electoral que revocan la inscripción de las candidaturas. De igual forma, si bien es cierto que se les permite a las organizaciones políticas sustituir el candidato revocado (siempre y cuando la decisión tenga lugar al menos un mes antes del certamen electoral), se suspende y afecta el ejercicio del derecho fundamental a ser elegido de quien se ve afectado con la decisión, esto como consecuencia de la inexistencia de acto administrativo que declare la elección.

La exposición realizada hasta acá pone en evidencia la existencia de una duplicidad de funciones en cabeza de autoridades distintas y con alcances diferentes. A pesar de que el objetivo de los dos instrumentos es garantizar el derecho al sufragio activo y pasivo, así como revestir de certeza al electorado y a quienes participan de la elección, en cuanto a la decisión que se adopta con ocasión de la jornada electoral, lo cierto es que dicho propósito no se ha alcanzado: primero, por las limitaciones que hemos explicado con relación a la revocatoria, y segundo, porque, a pesar del carácter definitivo de la decisión judicial, no siempre la misma es expedita.

La anterior afirmación se soporta en el hecho de que un año después de conformado el Congreso de la República no se han decidido la totalidad de los procesos judiciales promovidos con fundamento en la existencia de causales subjetivas de nulidad electoral. De los 33 procesos, hace falta adoptar una decisión de fondo en tres.

Lo dicho nos permite proponer el modelo de control de las candidaturas, el cual debe contemplar un procedimiento judicial que se caracterice por ser previo, autónomo, integral, célere, preclusivo y definitivo. Previo, por cuanto debe tener lugar antes de la celebración de las elecciones; autónomo, de tal manera que permita recurrir jurisdiccionalmente el acto de proclamación de candidaturas de forma independiente a la nulidad electoral; integral, porque el control debe recaer sobre la totalidad de la candidatura, es decir, confrontar tanto los aspectos formales como los sustanciales, y en relación con las inhabilidades debe dar lugar a la revisión de todas las causales y no solo a las derivadas de la potestad sancionatoria del Estado; y célere, preclusivo $y$ definitivo, de manera de contemplar términos cortos y perentorios para el ejercicio de los mecanismos previstos e impedir la posibilidad de continuar con la siguiente etapa del proceso electoral hasta tanto no se resuelvan de 
forma definitiva las controversias originadas con ocasión de la presentación de las candidaturas.

Finalmente, en lo que se refiere a la conducta desplegada por las distintas agrupaciones políticas, podemos sostener que, a pesar de la reducida capacidad sancionatoria del $\mathrm{CNE}^{50}$, existe un mayor compromiso de los partidos y movimientos políticos en el ejercicio del derecho a la postulación, del cual ellos son titulares con independencia de su tamaño u organización interna.

Esta afirmación encuentra asidero en el hecho de que solo en dos procesos de los 30 que a la fecha se han decidido en sede jurisdiccional el Consejo de Estado encontró mérito para declarar la nulidad de la elección, esto en el caso del senador Antanas Mockus, perteneciente al Partido Alianza Verde, y del representante a la Cámara por la circunscripción de Arauca, Luis Emilio Tovar Bello, miembro del Centro Democrático, al acreditar la configuración de causales de inelegibilidad.

\section{CONCLUSIONES}

1. La forma en la que se estableció el mecanismo y la ausencia de procedimiento autónomo y de criterios bien definidos para su aplicación generan vacíos y resultan insuficientes para mejorar las relaciones entre los ciudadanos y las organizaciones políticas.

Podría decirse que no terminan de responder a la necesidad de fortalecimiento de las organizaciones políticas y a la exigencia del principio de transparencia y probidad en la selección de sus candidatos. Da la impresión de que no hay ánimo suficiente de cumplir los principios que orientan las reformas de la representación política introducidas en el año 2003, y las competencias sancionatorias atribuidas al CNE parecen responder a coyunturas políticas, en vez de contribuir a un adecuado funcionamiento de las organizaciones y de la disciplina de partidos.

Así las cosas, la figura de la revocatoria de inscripción de candidaturas como está diseñada no permite mejorar el circuito de la representación política y fortalecer la democracia en Colombia puesto que no sirve de blindaje de las relaciones entre organizaciones políticas, representantes y electores.

2. El CNE no en todos los casos hace un análisis de fondo en los casos que resuelve. La inexistencia de un análisis sustancial implica que no haya una motivación suficiente que permita establecer la efectividad del mecanismo

50 En virtud de la Ley 1475 de 2011, en especial de los artículos 10, 11 y 12, el CNE tiene competencia para suspender el derecho de postulación de los partidos y movimientos políticos con personería jurídica, cancelar la personería jurídica de aquellas organizaciones que inscriban candidatos a cargos y corporaciones de elección popular que no reúnan los requisitos o calidades o se encuentren incursos en causales objetivas de inhabilidad. 
y su capacidad para garantizar el derecho al sufragio de los ciudadanos colombianos.

Por otra parte, la ausencia de regulación del mecanismo le da un amplio margen de discrecionalidad al CNE al momento de decidir sobre la revocatoria de las candidaturas y puede permitir arbitrariedades por depender exclusivamente de la interpretación de quienes lo conformen.

3. La revocatoria de la inscripción reporta niveles altos de eficacia respecto de las inhabilidades que tienen origen en el ejercicio de la potestad sancionatoria del Estado, toda vez que el cruce de información que adelanta con la Procuraduría General de la Nación permite identificar aquellas candidaturas con mácula por esta causal. Sin embargo, a pesar de dicha eficacia se expidió la Ley 1864 de 2017, la cual eleva a la categoría de delito la elección del candidato inhabilitado como consecuencia de una sentencia condenatoria penal, un fallo condenatorio disciplinario o un fallo de responsabilidad fiscal.

Lo anterior nos permite sostener que existe un alto nivel de desconfianza de las agrupaciones políticas respecto de la aplicación del instrumento de control por parte del CNE y, en general, del funcionamiento de la justicia electoral colombiana. Pues parece no ser suficiente la posibilidad de revocar la inscripción, declarar nula la elección y decretar la pérdida de investidura del congresista.

De allí la necesidad de pensar en que la transgresión al régimen de inhabilidades por parte de los candidatos, y, por lo tanto, la omisión del deber de diligencia que les asiste a las agrupaciones políticas, debe ser sancionada con la exclusión de los votos.

4. La revocatoria persigue la anulación de las candidaturas de personas individualmente consideradas -lo cual en principio no produciría un daño o efecto que exceda el ámbito personal-, pero puede ocurrir que mediante revocatorias sistemáticas de candidaturas se afecte la personería jurídica de los partidos políticos con ideologías políticas distintas a la que predomine dentro del CNE, constituyéndose en una amenaza de limitación al principio democrático, la cual puede ser especialmente latente en los casos de los candidatos inscritos por el partido FARC.

5. Hasta la fecha, el CNE ha actuado en cumplimiento de los compromisos adquiridos por el Gobierno Nacional en virtud de la suscripción del Acuerdo Final de Paz con las FARC-EP.

6. En la circunscripción ordinaria, el mayor número de revocatorias por causal de inhabilidad ha recaído sobre organizaciones creadas para la época electoral, carentes de una estructura robusta, como es el caso del Movimiento Todos Somos Colombia. Aunque se registran casos de partidos tradicionales -como el Liberal-o con organizaciones fuertes -como Cambio Radical-, el número es muy inferior. Esto nos permite concluir que las organizaciones políticas con una infraestructura organizada y con directivas con experiencia son una garantía de menores fallas en los controles. 
7. El diseño de la revocatoria no castiga a la organización política, por el contrario, le da la facultad para poder inscribir a otro candidato, siempre y cuando la revocatoria se decida al menos un mes antes de la celebración de las elecciones. Este diseño no se compagina con la apuesta de las reformas de la representación política introducidas desde el año 2003, que apuntan a un sistema electoral que privilegia las organizaciones fuertes, con una marcada organización democrática interna, y que sanciona a aquellas que no cumplen con los principios de transparencia, diligencia y probidad, entre otros.

8. La redacción de las causales de inhabilidad general y ambigua es utilizada por las organizaciones en su propio beneficio electoral, en desmedro del interés general y del ejercicio de los derechos políticos, desequilibrando las relaciones electorales entre las organizaciones y sacando provecho o ventajas indebidas en la competencia electoral.

9. Las reglas electorales que persiguen una mayor participación de las comunidades indígenas en los asuntos públicos imponen la necesidad de coordinación entre las autoridades nacionales y las indígenas en por los menos dos cuestiones: i) la definición de si las sanciones que han impuesto las comunidades son causales de inhabilidad y ii) cuál es la representación de los intereses de las comunidades en las candidaturas en la circunscripción ordinaria y en la especial.

10. La existencia del medio de control de nulidad electoral le resta efectividad al procedimiento, ya que si no se logra establecer la existencia de inhabilidades ante el $\mathrm{CNE}$, de todas formas puede demandarse el acto de elección del representante ante la Sección Quinta del Consejo de Estado alegando las mismas causales.

Respecto a lo anterior cabe preguntarse si no sería más efectivo establecer un único procedimiento que permitiera revocar, si no las candidaturas, los actos de elección de los candidatos, y ello dentro de un procedimiento que permitiera el cumplimiento equilibrado entre las garantías procesales y los derechos del electorado, mediante un examen más exhaustivo del material probatorio y con la posibilidad de efectuar un estudio de fondo de cada caso.

Por otro lado, ante el debate referente al diseño institucional que permite a entes de control y autoridades de naturaleza administrativa imponer sanciones limitadoras del ejercicio de los derechos políticos, es importante adelantar ajustes en el marco normativo, cuyo objeto sea articular el ordenamiento interno con las reglas del Sistema Interamericano de Derechos Humanos definidas en su corpus iuris.

11. Es necesaria la reestructuración del CNE como una autoridad de carácter judicial, o bien su supresión y la posterior creación de un tribunal electoral independiente. Solución que permitiría armonizar el diseño institucional colombiano con los tratados internacionales sobre derechos humanos y las interpretaciones que se han hecho de los mismos, así como con los fines 
esenciales de lucha contra la corrupción y promoción de la moralidad de la gestión administrativa.

\section{REFERENCIAS}

CRIADO DE DiEgo, M. Sobre el concepto de representación política: lineamientos para un estudio de las transformaciones de la democracia representativa. En Revista Derecho del Estado. N. ${ }^{\circ} 28,2012$.

Ferrajoli, L. "Principia iuris". Teoría del derecho y de la democracia. 2, Teoría de la democracia. Madrid: Trotta, 2011.

Fernández-Miranda y Campoamor, A. Artículo 70. 1: Causas de inelegibilidad e incompatibilidad y control judicial de las actas electorales. En Comentarios a las leyes políticas, Constitución española de 1978. T. Iv. Madrid: Edersa, 1989.

Padrón PARdo, F. El fortalecimiento de los partidos políticos, ¿una tarea pendiente? En Stefan, J. (ed.), 20 años de la Constitución colombiana: logros, retrocesos y agenda pendiente. Bogotá: Fundación Konrad Adenauer, 2012.

PAdRón PARdo, F. El concepto y función de las bancadas: las transformaciones de la representación política en Colombia. Bogotá: Universidad Externado de Colombia, 2015.

Padrón Pardo, F. y Correa Henao, M. (eds.). ¿El Estado constitucional en jaque? Los retos del componente democrático. Bogotá: Universidad Externado de Colombia, 2018.

Pascua, M. F. El control de las elecciones. Pamplona: Aranzadi, 2009.

Peña Jumpa, A. Multiculturalidad y Constitución: el caso de la Justicia Comunal Aguaruna en el Alto Marañón. Lima: Centro de Estudios Constitucionales, 2009.

Pitkin, H. F. The Concept of Representation. Berkeley: University of California Press, 1964.

Rico Marulanda, C. El concepto de inhabilidad en el ordenamiento jurídico colombiano. En Revista Centro de Estudios Políticos del Ministerio del Interior y de Justicia. Vol. 5, 2012.

Rico Marulanda, C. Las candidaturas independientes en el ordenamiento jurídico colombiano: ¿realidad o ficción? En Padrón Pardo, F. y Correa Henao, M. (eds.), ¿El Estado constitucional en jaque? Los retos del componente democrático. Bogotá: Universidad Externado de Colombia, 2018.

RoA RoA, J. La protección de derechos políticos frente a las funciones disciplinarias de las autoridades administrativas: subsidiariedad y deferencia en el Sistema Interamericano de Derechos Humanos. En Revista Brasileira de Políticas Públicas. Brazilian Journal of Public Policy. Vol. 8, n. ${ }^{\circ}$ 2, 2018.

SiEYÈs, E.-J. Sur l'organisation du pouvoir législatif et la sanction royale. En Les orateurs de la Révolution francaise. Paris: Bibliothéque de la Pléiade, 1989.

VANEGAS GiL, P. P. Las candidaturas en el derecho electoral colombiano. Bogotá: Universidad Externado de Colombia, 2009. 


\section{Jurisprudencia}

Consejo de Estado, Sala de lo Contencioso Administrativo, Sección Quinta. Sentencia del 31 de octubre de 2018. C.P.: Carlos Enrique Moreno Rubio. Rad. 11001-03-28-0002018-00032-00.

Consejo de Estado, Sala de lo Contencioso Administrativo, Sección Quinta. Sentencia del 25 de octubre de 2018. C.P.: Lucy Jeannette Bermúdez Bermúdez. Rad. 11001-03-28000-2018-00018-00.

Consejo de Estado, Sala de lo Contencioso Administrativo, Sección Quinta. Sentencia del 18 de octubre de 2018. C.P.: Alberto Yepes Barreiro. Rad. 11001-03-28-000-2018-00016-00.

Consejo de Estado, Sala de lo Contencioso Administrativo, Sección Quinta. Sentencia del 11 de octubre de 2018. C.P.: Lucy Jeannette Bermúdez Bermúdez. Rad. 11001-03-28000-2018-00028-00.

Consejo de Estado, Sala de lo Contencioso Administrativo, Sección Quinta. Sentencia del 11 de octubre de 2018. C.P.: Carlos Enrique Rubio. Rad. 11001-03-28-000-2018-00021-00.

Consejo de Estado, Sala de lo Contencioso Administrativo, Sección Quinta. Sentencia del 4 de octubre de 2018. C.P.: Carlos Enrique Moreno Rubio. Rad. 11001-03-28-0002018-00011-00.

Consejo de Estado, Sala de lo Contencioso Administrativo, Sección Quinta. Sentencia del 6 de septiembre de 2018. C.P.: Carlos Enrique Moreno Rubio. Rad. 11001-03-28000-2018-00014-00.

Consejo de Estado, Sala de lo Contencioso Administrativo, Sección Quinta. Sentencia del 30 de agosto de 2018. C.P.: Alberto Yepes Barreiro. Rad. 11001-03-28-000-2018-00026-00.

Consejo de Estado, Sala de lo Contencioso Administrativo, Sección Quinta. Sentencia del 13 de agosto de 2018. C.P.: Rocío Araújo Oñate. Rad. 11001-03-28-000-2018-00055-00.

Consejo de Estado, Sala de lo Contencioso Administrativo, Sección Quinta. Sentencia del 9 de agosto de 2018. C.P.: Lucy Jeannette Bermúdez Bermúdez. Rad. 11001-03-28000-2018-00008-00.

Consejo de Estado, Sala de lo Contencioso Administrativo, Sección Quinta. Sentencia del 23 de julio de 2018. C.P.: Rocío Araújo Oñate. Rad. 11001-03-28-000-2018-00031-00.

Consejo de Estado, Sala de lo Contencioso Administrativo, Sección Quinta. Sentencia del 18 de julio de 2018. C.P.: Carlos Enrique Moreno Rubio. Rad. 11001-03-28-0002018-00072-00.

Consejo de Estado, Sala de lo Contencioso Administrativo, Sección Quinta. Sentencia del 18 de julio de 2018. C.P.: Rocío Araújo Oñate. Rad. 11001-03-28-000-2018-00038-00.

Consejo de Estado, Sala de lo Contencioso Administrativo, Sección Quinta. Sentencia del 5 de julio de 2018. C.P.: Rocío Araújo Oñate. Rad. 11001-03-28-000-2018-00068-00.

Consejo de Estado, Sala de lo Contencioso Administrativo, Sección Quinta. Sentencia del 15 de junio de 2018. C.P.: Rocío Araújo Oñate. Rad. 11001-03-28-000-2018-00024-00. 
Consejo de Estado, Sala de lo Contencioso Administrativo, Sección Quinta. Sentencia del 31 de mayo de 2018. C.P.: Rocío Araújo Oñate. Rad. 11001-03-28-000-2018-00027-00.

Consejo de Estado, Sala de lo Contencioso Administrativo, Sección Quinta. Sentencia del 17 de mayo de 2018. C.P.: Carlos Enrique Moreno Rubio. Rad. 11001-03-28-0002017-00031-00.

Consejo de Estado, Sala de lo Contencioso Administrativo, Sección Quinta. Sentencia del 10 de mayo de 2018. C.P.: Rocío Araújo Oñate. Rad. 11001-03-28-000-2018-00012-00.

Consejo de Estado, Sala de lo Contencioso Administrativo, Sección Quinta. C.P.: Susana Buitrago Valencia. Sentencia del 14 de mayo de 2015. Rad. 11001-03-28-000-201400104-00.

Consejo de Estado, Sección Quinta. Sentencia del 26 de marzo de 2015. M.P.: Alberto Yepes. Rad. 11001-03-28-000-2014-00034-00.

Consejo de Estado, Sala de lo Contencioso Administrativo, Sección Quinta. Sentencia del 26 de febrero de 2015. M.P.: Alberto Yepes Barreiro. Rad. 11001-03-28-000-2014-00115-00.

Consejo de Estado. Sentencia del 6 de mayo de 2013. Rad. 11001-03-28-000-2011-00068-00.

Consejo de Estado. Sentencia del 20 de septiembre de 2007. Rad. 25000-23-25-000-200405226-01(0864-07).

Corte Constitucional. Sentencia su-264 de 2015.

Corte Constitucional. Sentencia T-642 de 2014.

Corte Constitucional. Sentencia C-437 de 2013. 
ANEXO

TABLA 1. PROCESOS PROMOVIDOS CONTRA LOS CANDIDATOS INSCRITOS POR LA CIRCUNSCRIPCIÓN ORDINARIA

\begin{tabular}{|c|c|c|c|c|c|}
\hline N. ${ }^{o}$ & Resolución & Candidato & $\begin{array}{l}\text { Corporación/ } \\
\text { Agrupación } \\
\text { política }\end{array}$ & $\begin{array}{l}\text { Causal de la } \\
\text { solicitud }\end{array}$ & $\begin{array}{c}\text { Motivos de la decisión } \\
\text { - Existencia de plena } \\
\text { prueba }\end{array}$ \\
\hline 1 & $\begin{array}{l}142 \text { del } 6 \text { de } \\
\text { febrero de } \\
2018\end{array}$ & $\begin{array}{l}\text { Yaddy Mancera } \\
\text { Rodríguez }\end{array}$ & $\begin{array}{l}\text { Cámara de } \\
\text { Representantes } \\
\text { - Cundinamarca - } \\
\text { Partido Liberal }\end{array}$ & $\begin{array}{l}\text { Art. } 179 \text { num. } \\
1 \mathrm{CP}\end{array}$ & $\begin{array}{l}\text { Existe plena prueba } \\
\text { de la existencia de la } \\
\text { inhabilidad }\end{array}$ \\
\hline 2 & $\begin{array}{l}143 \text { del } 6 \text { de } \\
\text { febrero de } \\
2018\end{array}$ & $\begin{array}{l}\text { Horacio José } \\
\text { Serpa Moncada }\end{array}$ & $\begin{array}{l}\text { Senado - Partido } \\
\text { Liberal }\end{array}$ & $\begin{array}{l}\text { Art. } 280 \text { num. } 8 \\
\text { Ley } 5 \text { de } 1992 \\
\text { - Art. } 179 \text { num. } \\
8 \text { CP }\end{array}$ & $\begin{array}{l}\text { No existe } \\
\text { prohibición para } \\
\text { que concejales o } \\
\text { diputados renuncien } \\
\text { para ser congresistas }\end{array}$ \\
\hline 3 & $\begin{array}{l}144 \text { del } 6 \text { de } \\
\text { febrero de } \\
2018\end{array}$ & $\begin{array}{l}\text { Carlos Julio } \\
\text { Barragán } \\
\text { Meneses }\end{array}$ & $\begin{array}{l}\text { Senado - Partido } \\
\text { Opción Ciudadana }\end{array}$ & $\begin{array}{l}\text { Art. } 179 \text { num. } \\
1 \mathrm{CP}\end{array}$ & $\begin{array}{l}\text { Ausencia de } \\
\text { plena prueba de la } \\
\text { inhabilidad }\end{array}$ \\
\hline 4 & $\begin{array}{l}145 \text { del } 6 \text { de } \\
\text { febrero de } \\
2018\end{array}$ & $\begin{array}{l}\text { Fabio Perdomo } \\
\text { Almeida }\end{array}$ & $\begin{array}{l}\text { Senado - Polo } \\
\text { Democrático }\end{array}$ & $\begin{array}{l}\text { Art. } 179 \text { num. } \\
1 \mathrm{CP}\end{array}$ & $\begin{array}{l}\text { Ausencia de } \\
\text { plena prueba de la } \\
\text { inhabilidad }\end{array}$ \\
\hline 5 & $\begin{array}{l}146 \text { del } 6 \text { de } \\
\text { febrero de } \\
2018\end{array}$ & $\begin{array}{l}\text { Luis Alberto } \\
\text { Martínez } \\
\text { Romero }\end{array}$ & $\begin{array}{l}\text { Senado - Partido } \\
\text { Somos }\end{array}$ & $\begin{array}{l}\text { Art. } 179 \text { num. } \\
1 \mathrm{CP}\end{array}$ & $\begin{array}{l}\text { Ausencia de } \\
\text { plena prueba de la } \\
\text { inhabilidad }\end{array}$ \\
\hline 6 & $\begin{array}{l}147 \text { del } 6 \text { de } \\
\text { febrero de } \\
2018\end{array}$ & $\begin{array}{l}\text { Marlon } \\
\text { Monsalve } \\
\text { Ascanio }\end{array}$ & $\begin{array}{l}\text { Cámara de } \\
\text { Representantes - } \\
\text { Partido Liberal }\end{array}$ & $\begin{array}{l}\text { Art. } 179 \text { num. } \\
2 \mathrm{CP}\end{array}$ & $\begin{array}{l}\text { No existe inhabilidad } \\
\text { porque el demandado } \\
\text { no ejerce autoridad } \\
\text { política ni } \\
\text { administrativa }\end{array}$ \\
\hline 7 & $\begin{array}{l}149 \text { del } 6 \text { de } \\
\text { febrero de } \\
2018\end{array}$ & $\begin{array}{l}\text { Miguel Ángel } \\
\text { Sánchez } \\
\text { Vásquez }\end{array}$ & $\begin{array}{l}\text { Senado y Cámara } \\
\text { - Partido Liberal }\end{array}$ & $\begin{array}{l}\text { El demandado } \\
\text { no tiene } \\
\text { competencia } \\
\text { para inscribir } \\
\text { candidatos en } \\
\text { nombre del } \\
\text { Partido Liberal }\end{array}$ & $\begin{array}{l}\text { CNE no tiene } \\
\text { competencia para } \\
\text { revocar inscripciones } \\
\text { de manera } \\
\text { generalizada }\end{array}$ \\
\hline 8 & $\begin{array}{l}150 \text { del } 6 \text { de } \\
\text { febrero de } \\
2018\end{array}$ & $\begin{array}{l}\text { José Omar } \\
\text { Murillo Angulo }\end{array}$ & $\begin{array}{l}\text { Cámara de } \\
\text { Representantes } \\
\text { - Partido } \\
\text { Alianza Social } \\
\text { Independiente } \\
\text { (ASI) }\end{array}$ & $\begin{array}{l}\text { Art. } 179 \text { num. } \\
1 \mathrm{CP}\end{array}$ & $\begin{array}{l}\text { Existe plena prueba } \\
\text { de la existencia de la } \\
\text { inhabilidad }\end{array}$ \\
\hline 9 & $\begin{array}{l}151 \text { del } 6 \text { de } \\
\text { febrero de } \\
2018\end{array}$ & $\begin{array}{l}\text { Antonio José } \\
\text { Pabón Pedraza }\end{array}$ & $\begin{array}{l}\text { Senado - } \\
\text { Movimiento } \\
\text { Político Todos } \\
\text { Somos Colombia }\end{array}$ & $\begin{array}{l}\text { Art. } 179 \text { num. } \\
1 \mathrm{CP}\end{array}$ & $\begin{array}{l}\text { Ausencia de } \\
\text { plena prueba de la } \\
\text { inhabilidad }\end{array}$ \\
\hline 10 & $\begin{array}{l}153 \text { del } 6 \text { de } \\
\text { febrero de } \\
2018\end{array}$ & $\begin{array}{l}\text { Luis Roberto } \\
\text { Schamalbach }\end{array}$ & $\begin{array}{l}\text { Cámara de } \\
\text { Representantes - } \\
\text { Polo Democrático }\end{array}$ & $\begin{array}{l}\text { Art. } 280 \text { num. } 8 \\
\text { Ley } 5 \text { de } 1992 \\
\text { - Art. } 179 \text { num. } \\
8 \text { CP }\end{array}$ & $\begin{array}{l}\text { No existe plena } \\
\text { prueba de la } \\
\text { existencia de la } \\
\text { inhabilidad }\end{array}$ \\
\hline
\end{tabular}

(Continúa) 


\begin{tabular}{|c|c|c|c|c|c|}
\hline $\mathbf{N}^{o}$ & Resolución & Candidato & $\begin{array}{c}\text { Corporación/ } \\
\text { Agrupación } \\
\text { política }\end{array}$ & $\begin{array}{l}\text { Causal de la } \\
\text { solicitud }\end{array}$ & $\begin{array}{c}\text { Motivos de la decisión } \\
\text { - Existencia de plena } \\
\text { prueba }\end{array}$ \\
\hline 11 & $\begin{array}{l}156 \text { del } 6 \text { de } \\
\text { febrero de } \\
2018\end{array}$ & $\begin{array}{l}\text { David Felipe } \\
\text { Castillo } \\
\text { Cárdenas }\end{array}$ & $\begin{array}{l}\text { Senado - Partido } \\
\text { Cambio Radical }\end{array}$ & $\begin{array}{l}\text { Art. } 179 \text { num. } \\
8 \mathrm{CP}\end{array}$ & $\begin{array}{l}\text { No existe inhabilidad } \\
\text { porque el demandado } \\
\text { renunció a su cargo } \\
\text { de concejal }\end{array}$ \\
\hline 12 & $\begin{array}{l}157 \text { del } 6 \text { de } \\
\text { febrero de } \\
2018\end{array}$ & $\begin{array}{l}\text { Didier Lobo } \\
\text { Chinchiya }\end{array}$ & $\begin{array}{l}\text { Senado - Partido } \\
\text { Cambio Radical }\end{array}$ & $\begin{array}{l}\text { Art. } 31 \text { Ley } 1475 \\
\text { de } 2011 \text { (por } \\
\text { haber iniciado la } \\
\text { campaña antes } \\
\text { de los términos } \\
\text { establecidos) }\end{array}$ & $\begin{array}{l}\text { No es una causal de } \\
\text { inhabilidad }\end{array}$ \\
\hline 13 & $\begin{array}{l}158 \text { del } 6 \text { de } \\
\text { febrero de } \\
2018\end{array}$ & $\begin{array}{l}\text { Luis Alfredo } \\
\text { Carvajal } \\
\text { Barriga }\end{array}$ & $\begin{array}{l}\text { Cámara de } \\
\text { Representantes } \\
\text { - Bogotá D.C. } \\
\text { - Movimiento } \\
\text { Político Todos } \\
\text { Somos Colombia }\end{array}$ & $\begin{array}{l}\text { Art. } 179 \text { num. } \\
1 \mathrm{CP}\end{array}$ & $\begin{array}{l}\text { Existe plena prueba } \\
\text { de la inhabilidad que } \\
\text { impide el registro } \\
\text { como candidato }\end{array}$ \\
\hline 14 & $\begin{array}{l}159 \text { del } 6 \text { de } \\
\text { febrero de } \\
2018\end{array}$ & $\begin{array}{l}\text { Ernesto Daza } \\
\text { Sierra }\end{array}$ & $\begin{array}{l}\text { Senado - Cambio } \\
\text { Radical }\end{array}$ & $\begin{array}{l}\text { Art. } 179 \text { num. } \\
1 \mathrm{CP}\end{array}$ & $\begin{array}{l}\text { Existe plena prueba } \\
\text { de la existencia de la } \\
\text { inhabilidad }\end{array}$ \\
\hline 15 & $\begin{array}{l}162 \text { del } 6 \text { de } \\
\text { febrero de } \\
2018\end{array}$ & $\begin{array}{l}\text { Luis Alfonso } \\
\text { Gómez } \\
\text { Obonaga }\end{array}$ & $\begin{array}{l}\text { Cámara de } \\
\text { Representantes } \\
\text { - Valle del } \\
\text { Cauca - Partido } \\
\text { Alianza Social } \\
\text { Independiente } \\
\text { (ASI) }\end{array}$ & $\begin{array}{l}\text { Art. } 179 \text { num. } \\
1 \mathrm{CP}\end{array}$ & $\begin{array}{l}\text { Ausencia de } \\
\text { plena prueba de la } \\
\text { inhabilidad }\end{array}$ \\
\hline 16 & $\begin{array}{l}163 \text { del } 6 \text { de } \\
\text { febrero de } \\
2018\end{array}$ & $\begin{array}{l}\text { Wilmar } \\
\text { Hernán Reyes } \\
\text { Arismendi }\end{array}$ & $\begin{array}{l}\text { Cámara de } \\
\text { Representantes } \\
\text { - Bogotá D.C. - } \\
\text { Partido Somos }\end{array}$ & $\begin{array}{l}\text { Art. } 179 \text { num. } \\
1 \mathrm{CP}\end{array}$ & $\begin{array}{l}\text { Existe plena prueba } \\
\text { de la existencia de la } \\
\text { inhabilidad }\end{array}$ \\
\hline 17 & $\begin{array}{l}164 \text { del } 6 \text { de } \\
\text { febrero de } \\
2018\end{array}$ & $\begin{array}{l}\text { Rosmira } \\
\text { Rosario } \\
\text { Rivadeneira } \\
\text { Narváez }\end{array}$ & $\begin{array}{l}\text { Cámara de } \\
\text { Representantes } \\
\text { - Magdalena - } \\
\text { Partido Opción } \\
\text { Ciudadana }\end{array}$ & $\begin{array}{l}\text { Art. } 179 \text { num. } \\
1 \mathrm{CP}\end{array}$ & $\begin{array}{l}\text { Ausencia de } \\
\text { plena prueba de la } \\
\text { inhabilidad }\end{array}$ \\
\hline 18 & $\begin{array}{l}166 \text { del } 6 \text { de } \\
\text { febrero de } \\
2018\end{array}$ & $\begin{array}{l}\text { Rómulo Alfonso } \\
\text { Leal Leal }\end{array}$ & $\begin{array}{l}\text { Senado - Partido } \\
\text { Liberal }\end{array}$ & $\begin{array}{l}\text { Art. } 179 \text { num. } \\
1 \mathrm{CP}\end{array}$ & $\begin{array}{l}\text { Ausencia de } \\
\text { plena prueba de la } \\
\text { inhabilidad }\end{array}$ \\
\hline 19 & $\begin{array}{l}167 \text { del } 6 \text { de } \\
\text { febrero de } \\
2018\end{array}$ & $\begin{array}{l}\text { Carlos Octavio } \\
\text { Sarmiento } \\
\text { Granados }\end{array}$ & $\begin{array}{l}\text { Cámara de } \\
\text { Representantes - } \\
\text { Partido Cambio } \\
\text { Radical }\end{array}$ & $\begin{array}{l}\text { Art. } 179 \text { num. } \\
7 \mathrm{CP}\end{array}$ & $\begin{array}{l}\text { No existe prueba de } \\
\text { la doble nacionalidad } \\
\text { del candidato }\end{array}$ \\
\hline 20 & $\begin{array}{l}168 \text { del } 6 \text { de } \\
\text { febrero de } \\
2018\end{array}$ & $\begin{array}{l}\text { Rodolfo Ucrós } \\
\text { Rosales }\end{array}$ & $\begin{array}{l}\text { Cámara de } \\
\text { Representantes } \\
\text { - Partido Centro } \\
\text { Democrático }\end{array}$ & $\begin{array}{l}\text { Art. } 2 \text { Ley } 1475 \\
\text { de } 2011 \text { (doble } \\
\text { militancia) }\end{array}$ & $\begin{array}{l}\text { El demandado no } \\
\text { incurrió en doble } \\
\text { militancia, había } \\
\text { renunciado al Partido } \\
\text { Conservador }\end{array}$ \\
\hline 21 & $\begin{array}{l}169 \text { del } 6 \text { de } \\
\text { febrero de } \\
2018\end{array}$ & $\begin{array}{l}\text { Fernando David } \\
\text { Murgueitio }\end{array}$ & $\begin{array}{l}\text { Senado - Partido } \\
\text { Liberal }\end{array}$ & $\begin{array}{l}\text { Art. } 179 \text { num. } \\
1 \mathrm{CP}\end{array}$ & $\begin{array}{l}\text { No existe plena } \\
\text { prueba de condenas } \\
\text { judiciales en contra } \\
\text { del demandado }\end{array}$ \\
\hline
\end{tabular}




\begin{tabular}{|c|c|c|c|c|c|}
\hline N. ${ }^{\circ}$ & Resolución & Candidato & $\begin{array}{l}\text { Corporación/ } \\
\text { Agrupación } \\
\text { política }\end{array}$ & $\begin{array}{l}\text { Causal de la } \\
\text { solicitud }\end{array}$ & $\begin{array}{c}\text { Motivos de la decisión } \\
\text { - Existencia de plena } \\
\text { prueba }\end{array}$ \\
\hline 22 & $\begin{array}{l}170 \text { del } 6 \text { de } \\
\text { febrero de } \\
2018\end{array}$ & $\begin{array}{l}\text { Nelson } \\
\text { Enrique Parada } \\
\text { Santamaría }\end{array}$ & $\begin{array}{l}\text { Cámara de } \\
\text { Representantes - } \\
\text { Partido Cambio } \\
\text { Radical }\end{array}$ & $\begin{array}{l}\text { Art. } 179 \text { num. } \\
8 \mathrm{CP}\end{array}$ & $\begin{array}{l}\text { El demandado } \\
\text { renunció a su cargo } \\
\text { como concejal }\end{array}$ \\
\hline 23 & $\begin{array}{l}171 \text { del } 6 \text { de } \\
\text { febrero de } \\
2018\end{array}$ & $\begin{array}{l}\text { Martha Cecilia } \\
\text { Vargas Salinas }\end{array}$ & $\begin{array}{l}\text { Senado - } \\
\text { Movimiento } \\
\text { Político Todos } \\
\text { Somos Colombia }\end{array}$ & $\begin{array}{l}\text { Art. } 179 \text { num. } \\
1 \mathrm{CP}\end{array}$ & $\begin{array}{l}\text { Existe plena prueba } \\
\text { de la existencia de la } \\
\text { inhabilidad }\end{array}$ \\
\hline 24 & $\begin{array}{l}172 \text { del } 6 \text { de } \\
\text { febrero de } \\
2018\end{array}$ & $\begin{array}{l}\text { Yenny } \\
\text { Esperanza Rozo } \\
\text { Zambrano }\end{array}$ & $\begin{array}{l}\text { Senado - } \\
\text { Partido Centro } \\
\text { Democrático }\end{array}$ & $\begin{array}{l}\text { Art. } 179 \text { num. } \\
8 \mathrm{CP}\end{array}$ & $\begin{array}{l}\text { No existe plena } \\
\text { prueba de la } \\
\text { inhabilidad }\end{array}$ \\
\hline 25 & $\begin{array}{l}173 \text { del } 6 \text { de } \\
\text { febrero de } \\
2018\end{array}$ & $\begin{array}{l}\text { Henry } \\
\text { Aristizábal } \\
\text { Lago }\end{array}$ & $\begin{array}{l}\text { Cámara de } \\
\text { Representantes } \\
\text { - Valle del Cauca - } \\
\text { Partido Somos }\end{array}$ & $\begin{array}{l}\text { Art. } 179 \text { num. } \\
1 \mathrm{CP}\end{array}$ & $\begin{array}{l}\text { Existe plena prueba } \\
\text { de la existencia de la } \\
\text { inhabilidad }\end{array}$ \\
\hline 26 & $\begin{array}{l}174 \text { del } 6 \text { de } \\
\text { febrero de } \\
2018\end{array}$ & $\begin{array}{l}\text { Antonio } \\
\text { Eresmid } \\
\text { Sanguino Páez }\end{array}$ & $\begin{array}{l}\text { Senado - Alianza } \\
\text { Verde }\end{array}$ & $\begin{array}{l}\text { Art. } 179 \text { num. } \\
8 \mathrm{CP}\end{array}$ & $\begin{array}{l}\text { No existe plena } \\
\text { prueba de la } \\
\text { inhabilidad }\end{array}$ \\
\hline 27 & $\begin{array}{l}175 \text { del } 6 \text { de } \\
\text { febrero de } \\
2018\end{array}$ & $\begin{array}{l}\text { Juan Alcides } \\
\text { Santaella } \\
\text { Gutiérrez }\end{array}$ & $\begin{array}{l}\text { Cámara de } \\
\text { Representantes } \\
\text { - Partido Centro } \\
\text { Democrático }\end{array}$ & $\begin{array}{l}\text { Falta de } \\
\text { aceptación }\end{array}$ & $\begin{array}{l}\text { Se trata de una falla } \\
\text { formal que puede } \\
\text { ser subsanable, } \\
\text { el partido y el } \\
\text { candidato habían } \\
\text { cumplido con lo } \\
\text { establecido en } \\
\text { el artículo } 31 \text { de } \\
\text { la Ley } 1475 \text { de } \\
2011 \text { referente a } \\
\text { la modificación } \\
\text { de candidatos } \\
\text { por renuncia y no } \\
\text { aceptación, dentro } \\
\text { de los } 5 \text { para } \\
\text { modificarla }\end{array}$ \\
\hline 28 & $\begin{array}{l}176 \text { del } 6 \text { de } \\
\text { febrero de } \\
2018\end{array}$ & $\begin{array}{l}\text { Vladimir Tete } \\
\text { Escobar }\end{array}$ & $\begin{array}{l}\text { Cámara de } \\
\text { Representantes } \\
\text { - Partido } \\
\text { Conservador }\end{array}$ & $\begin{array}{l}\text { Art. } 179 \text { num. } \\
1 \mathrm{CP}\end{array}$ & $\begin{array}{l}\text { El candidato no } \\
\text { tiene condena penal } \\
\text { ejecutoriada, está en } \\
\text { casación }\end{array}$ \\
\hline 29 & $\begin{array}{l}177 \text { del } 6 \text { de } \\
\text { febrero de } \\
2018\end{array}$ & $\begin{array}{l}\text { Alexander } \\
\text { Ortega Ordóñez }\end{array}$ & $\begin{array}{l}\text { Cámara de } \\
\text { Representantes - } \\
\text { Cauca - Partido } \\
\text { Somos }\end{array}$ & $\begin{array}{l}\text { Art. } 179 \text { num. } \\
1 \mathrm{CP}\end{array}$ & $\begin{array}{l}\text { Ausencia de } \\
\text { plena prueba de la } \\
\text { inhabilidad }\end{array}$ \\
\hline 30 & $\begin{array}{l}178 \text { del } 6 \text { de } \\
\text { febrero de } \\
2018\end{array}$ & $\begin{array}{l}\text { Carlos Alberto } \\
\text { Gómez Gómez }\end{array}$ & $\begin{array}{l}\text { Senado - } \\
\text { Partido Centro } \\
\text { Democrático }\end{array}$ & $\begin{array}{l}\text { Art. } 179 \text { num. } \\
2 \mathrm{CP}\end{array}$ & $\begin{array}{l}\text { No se demostró } \\
\text { que el candidato } \\
\text { estuviese } \\
\text { inhabilitado }\end{array}$ \\
\hline 31 & $\begin{array}{l}179 \text { del } 8 \text { de } \\
\text { febrero de } \\
2018\end{array}$ & $\begin{array}{l}\text { Silvano Pinzón } \\
\text { Barbosa }\end{array}$ & $\begin{array}{l}\text { Senado - } \\
\text { Movimiento } \\
\text { Político Todos } \\
\text { Somos Colombia }\end{array}$ & $\begin{array}{l}\text { Art. } 179 \text { num. } \\
1 \mathrm{CP}\end{array}$ & $\begin{array}{l}\text { Existe plena prueba } \\
\text { de la existencia de la } \\
\text { inhabilidad }\end{array}$ \\
\hline
\end{tabular}

(Continúa) 


\begin{tabular}{|c|c|c|c|c|c|}
\hline $\mathbf{N}^{o}$ & Resolución & Candidato & $\begin{array}{l}\text { Corporación/ } \\
\text { Agrupación } \\
\text { política }\end{array}$ & $\begin{array}{l}\text { Causal de la } \\
\text { solicitud }\end{array}$ & $\begin{array}{c}\text { Motivos de la decisión } \\
\text { - Existencia de plena } \\
\text { prueba }\end{array}$ \\
\hline 32 & $\begin{array}{l}182 \text { del } 30 \\
\text { de enero de } \\
2018\end{array}$ & $\begin{array}{l}\text { Óscar Antonio } \\
\text { Rivera Mora }\end{array}$ & $\begin{array}{l}\text { Senado - Partido } \\
\text { Somos }\end{array}$ & $\begin{array}{l}\text { Art. } 179 \text { num. } \\
1 \mathrm{CP}\end{array}$ & $\begin{array}{l}\text { Ausencia de } \\
\text { plena prueba de la } \\
\text { inhabilidad }\end{array}$ \\
\hline 33 & $\begin{array}{l}183 \text { del } 30 \\
\text { de enero de } \\
2018\end{array}$ & $\begin{array}{l}\text { Jhon Harol } \\
\text { Suárez Vargas }\end{array}$ & $\begin{array}{l}\text { Senado - } \\
\text { Partido Centro } \\
\text { Democrático }\end{array}$ & $\begin{array}{l}\text { Art. } 179 \text { num. } \\
1 \mathrm{CP}\end{array}$ & $\begin{array}{l}\text { No existe plena } \\
\text { prueba de condena } \\
\text { penal ejecutoriada }\end{array}$ \\
\hline 34 & $\begin{array}{l}184 \text { del } 30 \\
\text { de enero de } \\
2018\end{array}$ & $\begin{array}{l}\text { Francisco } \\
\text { Pareja González }\end{array}$ & $\begin{array}{l}\text { Cámara de } \\
\text { Representantes } \\
\text { - Partido Unidad } \\
\text { Nacional }\end{array}$ & $\begin{array}{l}\text { Art. } 179 \text { num. } \\
1 \mathrm{CP}\end{array}$ & $\begin{array}{l}\text { No existe plena } \\
\text { prueba de condena } \\
\text { penal ejecutoriada }\end{array}$ \\
\hline 35 & $\begin{array}{l}210 \text { del } 8 \text { de } \\
\text { febrero de } \\
2018\end{array}$ & $\begin{array}{l}\text { Luz Adriana } \\
\text { Padilla } \\
\text { González }\end{array}$ & $\begin{array}{l}\text { Senado - } \\
\text { Movimiento } \\
\text { Político Todos } \\
\text { Somos Colombia }\end{array}$ & $\begin{array}{l}\text { Art. } 179 \text { num. } \\
1 \mathrm{CP}\end{array}$ & $\begin{array}{l}\text { Existe plena prueba } \\
\text { de la existencia de la } \\
\text { inhabilidad }\end{array}$ \\
\hline 36 & $\begin{array}{l}211 \text { del } 8 \text { de } \\
\text { febrero de } \\
2018\end{array}$ & $\begin{array}{l}\text { Diego Fernando } \\
\text { Ospina } \\
\text { Marulanda }\end{array}$ & $\begin{array}{l}\text { Senado - } \\
\text { Movimiento } \\
\text { Político Todos } \\
\text { Somos Colombia }\end{array}$ & $\begin{array}{l}\text { Art. } 179 \text { num. } \\
1 \mathrm{CP}\end{array}$ & $\begin{array}{l}\text { Existe plena prueba } \\
\text { de la existencia de la } \\
\text { inhabilidad }\end{array}$ \\
\hline 37 & $\begin{array}{l}212 \text { del } 8 \text { de } \\
\text { febrero de } \\
2018\end{array}$ & $\begin{array}{l}\text { Harold } \\
\text { Fernando Urrea } \\
\text { Amaya }\end{array}$ & $\begin{array}{l}\text { Cámara de } \\
\text { Representantes - } \\
\text { Partido de la U }\end{array}$ & $\begin{array}{l}\text { Art. } 179 \text { num. } \\
8 \mathrm{CP}\end{array}$ & $\begin{array}{l}\text { El candidato } \\
\text { renunció a su cargo } \\
\text { como diputado en } \\
\text { tiempo, por lo que no } \\
\text { está inhabilitado }\end{array}$ \\
\hline 38 & $\begin{array}{l}216 \text { del } 8 \text { de } \\
\text { febrero de } \\
2018\end{array}$ & $\begin{array}{l}\text { Jorge Tobías } \\
\text { Arciniegas } \\
\text { Erazo - Yule } \\
\text { Vianey Anzueta }\end{array}$ & $\begin{array}{l}\text { Cámara de } \\
\text { Representantes - } \\
\text { Alianza Verde }\end{array}$ & $\begin{array}{l}\text { El candidato } \\
\text { no reside en el } \\
\text { departamento de } \\
\text { Putumayo }\end{array}$ & $\begin{array}{l}\text { La CP no estableció } \\
\text { este hecho como } \\
\text { restricción ni causal } \\
\text { de inhabilidad }\end{array}$ \\
\hline 39 & $\begin{array}{l}217 \text { del } 8 \text { de } \\
\text { febrero de } \\
2018\end{array}$ & $\begin{array}{l}\text { Moisés Reyes } \\
\text { Reyes }\end{array}$ & $\begin{array}{l}\text { Senado - } \\
\text { Movimiento } \\
\text { Político Todos } \\
\text { Somos Colombia }\end{array}$ & $\begin{array}{l}\text { Art. } 179 \text { num. } \\
1 \mathrm{CP}\end{array}$ & $\begin{array}{l}\text { Existe plena prueba } \\
\text { de la existencia de la } \\
\text { inhabilidad }\end{array}$ \\
\hline 40 & $\begin{array}{l}221 \text { del } 8 \text { de } \\
\text { febrero de } \\
2018\end{array}$ & $\begin{array}{l}\text { Aneley Marín } \\
\text { Plazas }\end{array}$ & $\begin{array}{l}\text { Cámara de } \\
\text { Representantes - } \\
\text { Partido Liberal }\end{array}$ & $\begin{array}{l}\text { Art. } 179 \text { num. } \\
4 \mathrm{CP}\end{array}$ & $\begin{array}{l}\text { La candidata no } \\
\text { fue condenada } \\
\text { por pérdida de } \\
\text { investidura, solo fue } \\
\text { declarada la nulidad } \\
\text { de su elección } \\
\text { como diputada. } \\
\text { No se configura la } \\
\text { inhabilidad }\end{array}$ \\
\hline 41 & $\begin{array}{l}223 \text { del } 8 \text { de } \\
\text { febrero de } \\
2018\end{array}$ & $\begin{array}{l}\text { Raúl Antonio } \\
\text { Narváez Macías }\end{array}$ & $\begin{array}{l}\text { Senado - } \\
\text { Movimiento } \\
\text { Político Todos } \\
\text { Somos Colombia }\end{array}$ & $\begin{array}{l}\text { Art. } 179 \text { num. } \\
1 \mathrm{CP}\end{array}$ & $\begin{array}{l}\text { Existe plena prueba } \\
\text { de la existencia de la } \\
\text { inhabilidad }\end{array}$ \\
\hline 42 & $\begin{array}{l}224 \text { del } 8 \text { de } \\
\text { febrero de } \\
2018\end{array}$ & $\begin{array}{l}\text { Andrés Arturo } \\
\text { Rodas Gaitán }\end{array}$ & $\begin{array}{l}\text { Cámara de } \\
\text { Representantes } \\
\text { - Partido Centro } \\
\text { Democrático }\end{array}$ & $\begin{array}{l}\text { Art. } 179 \text { num. } 1 \\
\text { y } 8 \mathrm{CP}\end{array}$ & $\begin{array}{l}\text { El candidato no tiene } \\
\text { condenas y renunció } \\
\text { a su cargo como } \\
\text { diputado }\end{array}$ \\
\hline 43 & $\begin{array}{l}226 \text { del } 8 \text { de } \\
\text { febrero de } \\
2018\end{array}$ & $\begin{array}{l}\text { Alejandro de } \\
\text { Jesús Herrera } \\
\text { Bustillo }\end{array}$ & $\begin{array}{l}\text { Senado - Partido } \\
\text { Opción Ciudadana }\end{array}$ & $\begin{array}{l}\text { Art. } 179 \text { num. } \\
1 \mathrm{CP}\end{array}$ & $\begin{array}{l}\text { Ausencia de } \\
\text { plena prueba de la } \\
\text { inhabilidad }\end{array}$ \\
\hline
\end{tabular}




\begin{tabular}{|c|c|c|c|c|c|}
\hline N. ${ }^{\circ}$ & Resolución & Candidato & $\begin{array}{l}\text { Corporación/ } \\
\text { Agrupación } \\
\text { política }\end{array}$ & $\begin{array}{c}\text { Causal de la } \\
\text { solicitud }\end{array}$ & $\begin{array}{c}\text { Motivos de la decisión } \\
\text { - Existencia de plena } \\
\text { prueba }\end{array}$ \\
\hline 44 & $\begin{array}{l}230 \text { del } 8 \text { de } \\
\text { febrero de } \\
2018\end{array}$ & $\begin{array}{l}\text { Lorenza Salas } \\
\text { Palacios }\end{array}$ & $\begin{array}{l}\text { Cámara de } \\
\text { Representantes - } \\
\text { Partido de la U }\end{array}$ & $\begin{array}{l}\text { Art. } 2 \text { Ley } 1475 \\
\text { de } 2011 \text { (doble } \\
\text { militancia) }\end{array}$ & $\begin{array}{l}\text { No existe plena } \\
\text { prueba de la doble } \\
\text { militancia }\end{array}$ \\
\hline 45 & $\begin{array}{l}231 \text { del } 8 \text { de } \\
\text { febrero de } \\
2018\end{array}$ & $\begin{array}{l}\text { Yeison Efraín } \\
\text { Pineda Alfonso }\end{array}$ & $\begin{array}{l}\text { Cámara de } \\
\text { Representantes - } \\
\text { Partido Liberal }\end{array}$ & $\begin{array}{l}\text { Art. } 2 \text { Ley } 1475 \\
\text { de } 2011 \text { (doble } \\
\text { militancia) }\end{array}$ & $\begin{array}{l}\text { No existe plena } \\
\text { prueba de la doble } \\
\text { militancia }\end{array}$ \\
\hline 46 & $\begin{array}{l}238 \text { del } 8 \\
\text { de enero de } \\
2018\end{array}$ & $\begin{array}{l}\text { Álvaro Guzmán } \\
\text { Orjuela }\end{array}$ & $\begin{array}{l}\text { Senado - } \\
\text { Partido Centro } \\
\text { Democrático }\end{array}$ & Art. 179 num. 4 & $\begin{array}{l}\text { El candidato perdió } \\
\text { su investidura como } \\
\text { concejal, no como } \\
\text { congresista, por lo } \\
\text { que no se configura } \\
\text { la inhabilidad }\end{array}$ \\
\hline 47 & $\begin{array}{l}245 \text { del } 8 \text { de } \\
\text { febrero de } \\
2018\end{array}$ & $\begin{array}{l}\text { Sara Elena } \\
\text { Piedrahíta } \\
\text { Lyons }\end{array}$ & $\begin{array}{l}\text { Cámara de } \\
\text { Representantes - } \\
\text { Partido de la U }\end{array}$ & $\begin{array}{l}\text { Financiación } \\
\text { ilegal de la } \\
\text { campaña y } \\
\text { violación de los } \\
\text { topes de gastos }\end{array}$ & $\begin{array}{l}\text { No se aportó } \\
\text { plena prueba de } \\
\text { la existencia de } \\
\text { ninguna inhabilidad }\end{array}$ \\
\hline 48 & $\begin{array}{l}258 \text { del } 9 \text { de } \\
\text { febrero de } \\
2018\end{array}$ & $\begin{array}{l}\text { Karina Espinosa } \\
\text { Oliver }\end{array}$ & $\begin{array}{l}\text { Cámara de } \\
\text { Representantes - } \\
\text { Partido Liberal }\end{array}$ & $\begin{array}{l}\text { Art. } 179 \text { num. } \\
5 \mathrm{CP}\end{array}$ & $\begin{array}{l}\text { Existe inhabilidad, } \\
\text { toda vez que la } \\
\text { candidata puede } \\
\text { beneficiarse del } \\
\text { reconocimiento } \\
\text { público de su } \\
\text { hermano como } \\
\text { viceministro de } \\
\text { Relaciones Políticas } \\
\text { del Ministerio del } \\
\text { Interior }\end{array}$ \\
\hline 49 & $\begin{array}{l}323 \text { del } 14 \\
\text { de febrero } \\
\text { de } 2018\end{array}$ & $\begin{array}{l}\text { Mateo Eduardo } \\
\text { Trujillo Segura }\end{array}$ & $\begin{array}{l}\text { Cámara de } \\
\text { Representantes } \\
\text { - Coalición } \\
\text { Colombia }\end{array}$ & $\begin{array}{l}\text { Art. } 179 \text { num. } \\
8 \mathrm{CP}\end{array}$ & $\begin{array}{l}\text { No existe plena } \\
\text { prueba de la } \\
\text { inhabilidad }\end{array}$ \\
\hline 50 & $\begin{array}{l}324 \text { del } 14 \\
\text { de febrero } \\
\text { de } 2018\end{array}$ & $\begin{array}{l}\text { Carlos Andrés } \\
\text { Benítez Avilés }\end{array}$ & $\begin{array}{l}\text { Cámara de } \\
\text { Representantes } \\
\text { - Coalición } \\
\text { Colombia }\end{array}$ & $\begin{array}{l}\text { Art. } 179 \text { num. } \\
1 \mathrm{CP}\end{array}$ & $\begin{array}{l}\text { A la fecha de } \\
\text { la decisión no } \\
\text { existía condena } \\
\text { judicial en firme } \\
\text { que configurara la } \\
\text { inhabilidad }\end{array}$ \\
\hline 51 & $\begin{array}{l}325 \text { del } 14 \\
\text { de febrero } \\
\text { de } 2018\end{array}$ & $\begin{array}{l}\text { Sandra Yaneth } \\
\text { Jaimes Cruz }\end{array}$ & $\begin{array}{l}\text { Cámara de } \\
\text { Representantes } \\
\text { - Coalición } \\
\text { Alternativa } \\
\text { Santandereana }\end{array}$ & $\begin{array}{l}\text { Art. } 179 \text { num. } \\
2 \mathrm{CP}\end{array}$ & $\begin{array}{l}\text { No existe plena } \\
\text { prueba de la } \\
\text { inhabilidad }\end{array}$ \\
\hline 52 & $\begin{array}{l}326 \text { del } 14 \\
\text { de febrero } \\
\text { de } 2018\end{array}$ & $\begin{array}{l}\text { César Augusto } \\
\text { Lorduy } \\
\text { Maldonado }\end{array}$ & $\begin{array}{l}\text { Cámara de } \\
\text { Representantes - } \\
\text { Partido Cambio } \\
\text { Radical }\end{array}$ & $\begin{array}{l}\text { Art. } 179 \text { num. } 2 \\
\text { y } 8 \mathrm{CP}\end{array}$ & $\begin{array}{l}\text { No existe plena } \\
\text { prueba de la } \\
\text { inhabilidad }\end{array}$ \\
\hline
\end{tabular}

(Continúa) 


\begin{tabular}{|c|c|c|c|c|c|}
\hline N. ${ }^{\circ}$ & Resolución & Candidato & $\begin{array}{l}\text { Corporación/ } \\
\text { Agrupación } \\
\text { política }\end{array}$ & $\begin{array}{l}\text { Causal de la } \\
\text { solicitud }\end{array}$ & $\begin{array}{c}\text { Motivos de la decisión } \\
\text { - Existencia de plena } \\
\text { prueba }\end{array}$ \\
\hline 53 & $\begin{array}{l}327 \text { del } 14 \\
\text { de febrero } \\
\text { de } 2018\end{array}$ & $\begin{array}{l}\text { Hearneldo José } \\
\text { Brito Durán }\end{array}$ & $\begin{array}{l}\text { Cámara de } \\
\text { Representantes - } \\
\text { Partido Liberal }\end{array}$ & $\begin{array}{l}\text { Renuncia a su } \\
\text { militancia por el } \\
\text { Partido Liberal, } \\
\text { así como al aval } \\
\text { otorgado por el } \\
\text { partido }\end{array}$ & $\begin{array}{l}\text { No procede la } \\
\text { revocatoria porque } \\
\text { el supuesto de hecho } \\
\text { no se enmarca en } \\
\text { ninguna causal } \\
\text { taxativa }\end{array}$ \\
\hline 54 & $\begin{array}{l}329 \text { del } 14 \\
\text { de febrero } \\
\text { de } 2018\end{array}$ & $\begin{array}{l}\text { Didier Lobo } \\
\text { Chinchiya }\end{array}$ & $\begin{array}{l}\text { Senado - Partido } \\
\text { Cambio Radical }\end{array}$ & $\begin{array}{l}\text { Art. } 179 \text { num. } \\
1 \mathrm{CP}\end{array}$ & $\begin{array}{l}\text { El demandado no } \\
\text { tiene antecedentes } \\
\text { disciplinarios ni } \\
\text { condenas judiciales } \\
\text { en firme }\end{array}$ \\
\hline 55 & $\begin{array}{l}399 \text { del } 21 \\
\text { de febrero } \\
\text { de } 2018\end{array}$ & $\begin{array}{l}\text { Alejandro Pérez } \\
\text { Prada }\end{array}$ & $\begin{array}{l}\text { Cámara de } \\
\text { Representantes } \\
\text { - Partido } \\
\text { Conservador }\end{array}$ & $\begin{array}{l}\text { Art. } 179 \text { num. } \\
1 \mathrm{CP}\end{array}$ & $\begin{array}{l}\text { El demandado no } \\
\text { tiene antecedentes } \\
\text { disciplinarios ni } \\
\text { condenas judiciales } \\
\text { en firme }\end{array}$ \\
\hline 56 & $\begin{array}{l}403 \text { del } 21 \\
\text { de febrero } \\
\text { de } 2018\end{array}$ & $\begin{array}{l}\text { José Ovidio } \\
\text { Claros Polanco }\end{array}$ & $\begin{array}{l}\text { Senado - Partido } \\
\text { Cambio Radical }\end{array}$ & $\begin{array}{l}\text { Art. } 179 \text { num. } \\
1 \mathrm{CP}\end{array}$ & $\begin{array}{l}\text { El demandado no } \\
\text { tiene antecedentes } \\
\text { disciplinarios ni } \\
\text { condenas judiciales } \\
\text { en firme }\end{array}$ \\
\hline 57 & $\begin{array}{l}407 \text { del } 21 \\
\text { de febrero } \\
\text { de } 2018\end{array}$ & $\begin{array}{l}\text { Ana Cecilia } \\
\text { García Sánchez }\end{array}$ & $\begin{array}{l}\text { Senado - } \\
\text { Movimiento } \\
\text { Político Todos } \\
\text { Somos Colombia } \\
\end{array}$ & $\begin{array}{l}\text { Art. } 179 \text { num. } \\
1 \mathrm{CP}\end{array}$ & $\begin{array}{l}\text { Ausencia de } \\
\text { plena prueba de la } \\
\text { inhabilidad }\end{array}$ \\
\hline 58 & $\begin{array}{l}408 \text { del } 19 \\
\text { de febrero } \\
\text { de } 208\end{array}$ & $\begin{array}{l}\text { Mariela Puerto } \\
\text { Álvarez }\end{array}$ & $\begin{array}{l}\text { Senado - Partido } \\
\text { de la Decencia }\end{array}$ & $\begin{array}{l}\text { Art. } 179 \text { num. } \\
5 \text { CP }\end{array}$ & $\begin{array}{l}\text { No se cumple } \\
\text { el requisito de } \\
\text { territorialidad } \\
\text { exigido por la } \\
\text { causal, no es } \\
\text { aplicable en casos de } \\
\text { coincidencia entre } \\
\text { la circunscripción } \\
\text { nacional y las } \\
\text { territoriales }\end{array}$ \\
\hline 59 & $\begin{array}{l}662 \text { del } 27 \\
\text { de febrero } \\
\text { de } 2018\end{array}$ & $\begin{array}{l}\text { Rosa Amparo } \\
\text { Quintana } \\
\text { Velásquez }\end{array}$ & $\begin{array}{l}\text { Senado - Partido } \\
\text { Liberal }\end{array}$ & $\begin{array}{l}\text { Art. } 179 \text { num. } \\
3 \mathrm{CP}\end{array}$ & $\begin{array}{l}\text { Se demostró que la } \\
\text { candidata suscribió } \\
\text { un contrato de } \\
\text { prestación de } \\
\text { servicios el } 25 \text { de } \\
\text { enero de } 2018, \\
\text { fecha posterior a } \\
\text { su inscripción pero } \\
\text { que configura la } \\
\text { inhabilidad }\end{array}$ \\
\hline
\end{tabular}


TABLA 2. PROCESOS PROMOVIDOS EN LA CIRCUNSCRIPCIÓN ESPECIAL DE COMUNIDADES AFRODESCENDIENTES

\begin{tabular}{|c|c|c|c|c|c|}
\hline N. ${ }^{\circ}$ & Resolución & Candidato & Agrupación política & $\begin{array}{l}\text { Causa de la } \\
\text { solicitud }\end{array}$ & $\begin{array}{l}\text { Motivos de } \\
\text { la decisión - } \\
\text { Existencia de } \\
\text { plena prueba }\end{array}$ \\
\hline 1 & $\begin{array}{l}214 \text { del } 8 \text { de } \\
\text { febrero de } \\
2018\end{array}$ & $\begin{array}{l}\text { Vanessa } \\
\text { Alexandra } \\
\text { Mendoza Bustos }\end{array}$ & $\begin{array}{l}\text { Consejo Comunitario } \\
\text { de la Comunidad } \\
\text { Negra de Limones }\end{array}$ & $\begin{array}{l}\text { Art. } 2 \text { Ley } 1475 \\
\text { de } 2011 \text { (doble } \\
\text { militancia) }\end{array}$ & $\begin{array}{l}\text { No se demostró } \\
\text { la existencia de } \\
\text { la causal }\end{array}$ \\
\hline 2 & $\begin{array}{l}218 \text { del } 8 \text { de } \\
\text { febrero de } \\
2018\end{array}$ & Toda la lista & $\begin{array}{l}\text { Fundación Étnica de } \\
\text { Colombia }\end{array}$ & $\begin{array}{l}\text { Incumplimiento } \\
\text { de los requisitos } \\
\text { del art. } 3 \text { de la } \\
\text { Ley } 649 \text { de } 2001\end{array}$ & $\begin{array}{l}\text { La organización } \\
\text { que otorgó } \\
\text { el aval a los } \\
\text { candidatos } \\
\text { no acreditó } \\
\text { su condición } \\
\text { de consejo } \\
\text { comunitario }\end{array}$ \\
\hline 3 & $\begin{array}{l}219 \text { del } 8 \text { de } \\
\text { febrero de } \\
2018\end{array}$ & Toda la lista & $\begin{array}{l}\text { Fundación Deportiva } \\
\text { Viáfara }\end{array}$ & $\begin{array}{l}\text { Incumplimiento } \\
\text { de los requisitos } \\
\text { del art. } 3 \text { de la } \\
\text { Ley } 649 \text { de } 2001\end{array}$ & $\begin{array}{l}\text { La organización } \\
\text { es de base y } \\
\text { no un consejo } \\
\text { comunitario }\end{array}$ \\
\hline 4 & $\begin{array}{l}220 \text { del } 8 \text { de } \\
\text { febrero de } \\
2018\end{array}$ & $\begin{array}{l}\text { Gustavo Adolfo } \\
\text { Prado Cardona }\end{array}$ & $\begin{array}{l}\text { Consejo Comunitario } \\
\text { Kusuto Magende } \\
\text { Cokumalu de Luruaco }\end{array}$ & $\begin{array}{l}\text { Los candidatos } \\
\text { no acreditaron } \\
\text { su pertenencia } \\
\text { al consejo } \\
\text { comunitario }\end{array}$ & $\begin{array}{l}\text { El consejo } \\
\text { comunitario } \\
\text { demostró que } \\
\text { los candidatos } \\
\text { hacían parte de } \\
\text { este desde hacía } \\
4 \text { años }\end{array}$ \\
\hline 5 & $\begin{array}{l}227 \text { del } 8 \text { de } \\
\text { febrero de } \\
2018\end{array}$ & $\begin{array}{l}\text { Martín Alonso } \\
\text { Vega Soto }\end{array}$ & $\begin{array}{l}\text { Asociación } \\
\text { Colombiana Negra } \\
\text { Huellas de Africanía } \\
\text { en Paz }\end{array}$ & $\begin{array}{l}\text { Art. } 179 \text { num. } \\
1 \mathrm{CP}\end{array}$ & $\begin{array}{l}\text { Existe plena } \\
\text { prueba de la } \\
\text { existencia de la } \\
\text { inhabilidad }\end{array}$ \\
\hline 6 & $\begin{array}{l}228 \text { del } 8 \\
\text { febrero de } \\
2018\end{array}$ & $\begin{array}{l}\text { Cristian Zuluaga } \\
\text { Mosquera }\end{array}$ & $\begin{array}{l}\text { Asociación } \\
\text { Afrocolombiana } \\
\text { de Asentamiento } \\
\text { Ancestral Municipio } \\
\text { de San Pedro }\end{array}$ & $\begin{array}{l}\text { Art. } 179 \text { num. } \\
1 \mathrm{CP}\end{array}$ & $\begin{array}{l}\text { Existe plena } \\
\text { prueba de la } \\
\text { existencia de la } \\
\text { inhabilidad }\end{array}$ \\
\hline 7 & $\begin{array}{l}229 \text { del } 8 \text { de } \\
\text { febrero de } \\
2018\end{array}$ & Toda la lista & $\begin{array}{l}\text { Organización } \\
\text { Afrocolombiana "Los } \\
\text { Palenkes" }\end{array}$ & $\begin{array}{l}\text { Incumplimiento } \\
\text { de los requisitos } \\
\text { del art. } 3 \text { de la } \\
\text { Ley } 649 \text { de } 2001\end{array}$ & $\begin{array}{l}\text { La organización } \\
\text { que otorgó } \\
\text { los avales no } \\
\text { se encuentra } \\
\text { inscrita ante la } \\
\text { Dirección de } \\
\text { Asuntos para las } \\
\text { Comunidades } \\
\text { Negras }\end{array}$ \\
\hline 8 & $\begin{array}{l}232 \text { del } 8 \text { de } \\
\text { febrero de } \\
2018\end{array}$ & Toda la lista & $\begin{array}{l}\text { Fundación } \\
\text { Afrocolombiana } \\
\text { Liberal de Desarrollo } \\
\text { Social }\end{array}$ & $\begin{array}{l}\text { Aval otorgado } \\
\text { por organización } \\
\text { distinta al } \\
\text { consejo } \\
\text { comunitario }\end{array}$ & $\begin{array}{l}\text { La organización } \\
\text { que otorgó } \\
\text { los avales no } \\
\text { ostenta calidad } \\
\text { de consejo } \\
\text { comunitario }\end{array}$ \\
\hline
\end{tabular}




\begin{tabular}{|c|c|c|c|c|c|}
\hline N. ${ }^{\circ}$ & Resolución & Candidato & Agrupación política & $\begin{array}{l}\text { Causa de la } \\
\text { solicitud }\end{array}$ & $\begin{array}{l}\text { Motivos de } \\
\text { la decisión - } \\
\text { Existencia de } \\
\text { plena prueba }\end{array}$ \\
\hline 9 & $\begin{array}{l}233 \text { del } 8 \text { de } \\
\text { febrero de } \\
2018\end{array}$ & Toda la lista & $\begin{array}{l}\text { Fundación Renacer } \\
\text { para Todos }\end{array}$ & $\begin{array}{l}\text { Aval otorgado } \\
\text { por organización } \\
\text { distinta al } \\
\text { consejo } \\
\text { comunitario }\end{array}$ & $\begin{array}{l}\text { La organización } \\
\text { que otorgó } \\
\text { los avales no } \\
\text { ostenta calidad } \\
\text { de consejo } \\
\text { comunitario }\end{array}$ \\
\hline 10 & $\begin{array}{l}234 \text { del } 8 \text { de } \\
\text { febrero de } \\
2018\end{array}$ & Toda la lista & $\begin{array}{l}\text { Organización Social } \\
\text { de Comunidades } \\
\text { Negras "Nelson } \\
\text { Mandela" }\end{array}$ & $\begin{array}{l}\text { Incumplimiento } \\
\text { de los requisitos } \\
\text { del art. } 3 \text { de la } \\
\text { Ley } 649 \text { de } 2001\end{array}$ & $\begin{array}{l}\text { La organización } \\
\text { no se ha } \\
\text { constituido } \\
\text { como consejo } \\
\text { comunitario y no } \\
\text { puede postular } \\
\text { candidatos }\end{array}$ \\
\hline 11 & $\begin{array}{l}235 \text { del } 8 \text { de } \\
\text { febrero de } \\
2018\end{array}$ & Toda la lista & $\begin{array}{l}\text { Asociación } \\
\text { Afrocolombiana } \\
\text { de Asentamiento } \\
\text { Ancestral Municipio } \\
\text { de San Pedro }\end{array}$ & $\begin{array}{l}\text { Incumplimiento } \\
\text { de los requisitos } \\
\text { del art. } 3 \text { de la } \\
\text { Ley } 649 \text { de } 2001\end{array}$ & $\begin{array}{l}\text { La organización } \\
\text { que otorgó los } \\
\text { avales no ostenta } \\
\text { la calidad } \\
\text { de consejo } \\
\text { comunitario }\end{array}$ \\
\hline 12 & $\begin{array}{l}236 \text { del } 8 \text { de } \\
\text { febrero de } \\
2018\end{array}$ & Toda la lista & $\begin{array}{l}\text { Asociación } \\
\text { Afrocolombianos Sin } \\
\text { Ánimo de Lucro de } \\
\text { San Cristóbal del Sur }\end{array}$ & $\begin{array}{l}\text { Incumplimiento } \\
\text { de los requisitos } \\
\text { del art. } 3 \text { de la } \\
\text { Ley } 649 \text { de } 2001\end{array}$ & $\begin{array}{l}\text { La organización } \\
\text { que otorgó } \\
\text { los avales no } \\
\text { se encuentra } \\
\text { inscrita ante la } \\
\text { Dirección de } \\
\text { Asuntos para las } \\
\text { Comunidades } \\
\text { Negras }\end{array}$ \\
\hline 13 & $\begin{array}{l}237 \text { del } 8 \text { de } \\
\text { febrero de } \\
2018\end{array}$ & Toda la lista & $\begin{array}{l}\text { Fundación Amor y } \\
\text { Paz }\end{array}$ & $\begin{array}{l}\text { Incumplimiento } \\
\text { de los requisitos } \\
\text { del art. } 3 \text { de la } \\
\text { Ley } 649 \text { de } 2001\end{array}$ & $\begin{array}{l}\text { La organización } \\
\text { que otorgó los } \\
\text { avales no ostenta } \\
\text { la calidad } \\
\text { de consejo } \\
\text { comunitario }\end{array}$ \\
\hline 14 & $\begin{array}{l}239 \text { del } 8 \text { de } \\
\text { febrero de } \\
2018\end{array}$ & $\begin{array}{l}\text { Yakson } \\
\text { Gutiérrez - José } \\
\text { Manuel Castro } \\
\text { - Edwin José } \\
\text { Bello }\end{array}$ & $\begin{array}{l}\text { Movimiento Todos } \\
\text { Somos Colombia }\end{array}$ & $\begin{array}{l}\text { Aval otorgado } \\
\text { por organización } \\
\text { distinta al } \\
\text { consejo } \\
\text { comunitario }\end{array}$ & $\begin{array}{l}\text { La organización } \\
\text { cumple con } \\
\text { los requisitos } \\
\text { para presentar } \\
\text { candidatos, } \\
\text { además de } \\
\text { encontrarse } \\
\text { inscrita ante el } \\
\text { Ministerio del } \\
\text { Interior }\end{array}$ \\
\hline 15 & $\begin{array}{l}240 \text { del } 8 \text { de } \\
\text { febrero de } \\
2018\end{array}$ & $\begin{array}{l}\text { Fredy Obando } \\
\text { - Helder Acosta } \\
\text { - Ana Ximena } \\
\text { Rivas }\end{array}$ & $\begin{array}{l}\text { Asociación } \\
\text { Afrocolombiana Sí Se } \\
\text { Puede }\end{array}$ & $\begin{array}{l}\text { Incumplimiento } \\
\text { de los requisitos } \\
\text { del art. } 3 \text { de la } \\
\text { Ley } 649 \text { de } 2001\end{array}$ & $\begin{array}{l}\text { La organización } \\
\text { no es un consejo } \\
\text { comunitario }\end{array}$ \\
\hline
\end{tabular}

(Continúa) 


\begin{tabular}{|c|c|c|c|c|c|}
\hline N. ${ }^{\circ}$ & Resolución & Candidato & Agrupación política & $\begin{array}{l}\text { Causa de la } \\
\text { solicitud }\end{array}$ & $\begin{array}{l}\text { Motivos de } \\
\text { la decisión - } \\
\text { Existencia de } \\
\text { plena prueba }\end{array}$ \\
\hline 16 & $\begin{array}{l}241 \text { del } 8 \text { de } \\
\text { febrero de } \\
2018\end{array}$ & $\begin{array}{l}\text { Jesús España } \\
\text { Mayorca - } \\
\text { Martín Alonso } \\
\text { Vega }\end{array}$ & $\begin{array}{l}\text { Asociación } \\
\text { Colombiana Negra } \\
\text { Huellas de Africanía } \\
\text { en Paz }\end{array}$ & $\begin{array}{l}\text { Incumplimiento } \\
\text { de los requisitos } \\
\text { del art. } 3 \text { de la } \\
\text { Ley } 649 \text { de } 2001\end{array}$ & $\begin{array}{l}\text { La asociación } \\
\text { que otorgó } \\
\text { el aval no se } \\
\text { encontraba } \\
\text { constituida } \\
\text { como consejo } \\
\text { comunitario }\end{array}$ \\
\hline 17 & $\begin{array}{l}242 \text { del } 8 \text { de } \\
\text { febrero de } \\
2018\end{array}$ & Toda la lista & $\begin{array}{l}\text { Fundación Laborar } \\
\text { por Colombia }\end{array}$ & $\begin{array}{l}\text { Incumplimiento } \\
\text { de los requisitos } \\
\text { del art. } 3 \text { de la } \\
\text { Ley } 649 \text { de } 2001\end{array}$ & $\begin{array}{l}\text { La organización } \\
\text { no ostenta } \\
\text { la calidad } \\
\text { de consejo } \\
\text { comunitario }\end{array}$ \\
\hline 18 & $\begin{array}{l}319 \text { del } 14 \\
\text { de febrero de } \\
2018\end{array}$ & Toda la lista & $\begin{array}{l}\text { Fundación } \\
\text { Afrodescendiente } \\
\text { Profesional de } \\
\text { Córdoba }\end{array}$ & $\begin{array}{l}\text { Incumplimiento } \\
\text { de los requisitos } \\
\text { del art. } 3 \text { de la } \\
\text { Ley } 649 \text { de } 2001\end{array}$ & $\begin{array}{l}\text { La organización } \\
\text { que otorgó los } \\
\text { avales no ostenta } \\
\text { la calidad } \\
\text { de consejo } \\
\text { comunitario }\end{array}$ \\
\hline 19 & $\begin{array}{l}320 \text { del } 14 \\
\text { de febrero de } \\
2018\end{array}$ & Toda la lista & $\begin{array}{l}\text { Agencia } \\
\text { Afrocolombiana } \\
\text { Empresa Asociativa } \\
\text { de Trabajo }\end{array}$ & $\begin{array}{l}\text { Incumplimiento } \\
\text { de los requisitos } \\
\text { del art. } 3 \text { de la } \\
\text { Ley } 649 \text { de } 2001\end{array}$ & $\begin{array}{l}\text { La organización } \\
\text { que otorgó los } \\
\text { avales no ostenta } \\
\text { la calidad } \\
\text { de consejo } \\
\text { comunitario }\end{array}$ \\
\hline 20 & $\begin{array}{l}321 \text { del } 14 \\
\text { de febrero de } \\
2018\end{array}$ & $\begin{array}{l}\text { Jhobany } \\
\text { Andrés Caicedo } \\
\text { - Ramón } \\
\text { Hernando } \\
\text { Aguirre - Édgar } \\
\text { José Obando }\end{array}$ & $\begin{array}{l}\text { Consejo Comunitario } \\
\text { Deimbilpi del Carmen }\end{array}$ & $\begin{array}{l}\text { Aval otorgado } \\
\text { por organización } \\
\text { distinta al } \\
\text { consejo } \\
\text { comunitario }\end{array}$ & $\begin{array}{l}\text { La organización } \\
\text { cumple con } \\
\text { los requisitos } \\
\text { para presentar } \\
\text { candidatos, } \\
\text { además de } \\
\text { encontrarse } \\
\text { inscrita ante el } \\
\text { Ministerio del } \\
\text { Interior }\end{array}$ \\
\hline 21 & $\begin{array}{l}332 \text { del } 14 \\
\text { de febrero de } \\
2018\end{array}$ & Toda la lista & $\begin{array}{l}\text { Asociación Centro de } \\
\text { Autoreconocimiento } \\
\text { Afrocolombiano } \\
\text { CENAFRO }\end{array}$ & $\begin{array}{l}\text { Incumplimiento } \\
\text { de los requisitos } \\
\text { del art. } 3 \text { de la } \\
\text { Ley } 649 \text { de } 2001\end{array}$ & $\begin{array}{l}\text { La organización } \\
\text { que otorgó } \\
\text { los avales no } \\
\text { se encuentra } \\
\text { inscrita ante la } \\
\text { Dirección de } \\
\text { Asuntos para las } \\
\text { Comunidades } \\
\text { Negras }\end{array}$ \\
\hline
\end{tabular}

(Continúa) 


\begin{tabular}{|c|c|c|c|c|c|}
\hline N. ${ }^{\circ}$ & Resolución & Candidato & Agrupación política & $\begin{array}{l}\text { Causa de la } \\
\text { solicitud }\end{array}$ & $\begin{array}{l}\text { Motivos de } \\
\text { la decisión - } \\
\text { Existencia de } \\
\text { plena prueba }\end{array}$ \\
\hline 22 & $\begin{array}{l}333 \text { del } 14 \\
\text { de febrero de } \\
2018\end{array}$ & Toda la lista & $\begin{array}{l}\text { Corporación Poder } \\
\text { Ciudadano }\end{array}$ & $\begin{array}{l}\text { Aval otorgado } \\
\text { por organización } \\
\text { distinta al } \\
\text { consejo } \\
\text { comunitario }\end{array}$ & $\begin{array}{l}\text { La organización } \\
\text { cumple con } \\
\text { los requisitos } \\
\text { para presentar } \\
\text { candidatos, } \\
\text { además de } \\
\text { encontrarse } \\
\text { inscrita ante el } \\
\text { Ministerio del } \\
\text { Interior }\end{array}$ \\
\hline 23 & $\begin{array}{l}334 \text { del } 14 \text { de } \\
\text { febrero } 2018\end{array}$ & Toda la lista & $\begin{array}{l}\text { Fundación Esperanza } \\
\text { AFRO }\end{array}$ & $\begin{array}{l}\text { Incumplimiento } \\
\text { de los requisitos } \\
\text { del art. } 3 \text { de la } \\
\text { Ley } 649 \text { de } 2001\end{array}$ & $\begin{array}{l}\text { La organización } \\
\text { que otorgó } \\
\text { los avales no } \\
\text { se encuentra } \\
\text { inscrita ante la } \\
\text { Dirección de } \\
\text { Asuntos para las } \\
\text { Comunidades } \\
\text { Negras }\end{array}$ \\
\hline 24 & $\begin{array}{l}335 \text { de } 14 \text { de } \\
\text { febrero de } \\
2018\end{array}$ & $\begin{array}{l}\text { Todas las listas } \\
\text { inscritas en la } \\
\text { circunscripción }\end{array}$ & & $\begin{array}{l}\text { Aval otorgado } \\
\text { por organización } \\
\text { distinta al } \\
\text { consejo } \\
\text { comunitario }\end{array}$ & $\begin{array}{l}\text { No existe sujeto } \\
\text { pasivo al cual } \\
\text { revocar la } \\
\text { inscripción de la } \\
\text { candidatura. Se } \\
\text { negó de plano } \\
\text { la solicitud } \\
\text { por tratarse de } \\
\text { pretensiones } \\
\text { de carácter } \\
\text { indeterminado }\end{array}$ \\
\hline 25 & $\begin{array}{l}400 \text { del } 21 \\
\text { de febrero de } \\
2018\end{array}$ & $\begin{array}{l}\text { Ana Milena } \\
\text { Cadena - Luz } \\
\text { Míryam } \\
\text { Mosquera } \\
\text { - Hernán } \\
\text { Banguero } \\
\text { Andrade }\end{array}$ & $\begin{array}{l}\text { Consejo Comunitario } \\
\text { La Mamumcia }\end{array}$ & $\begin{array}{l}\text { Aval otorgado } \\
\text { por organización } \\
\text { distinta al } \\
\text { consejo } \\
\text { comunitario }\end{array}$ & $\begin{array}{l}\text { La organización } \\
\text { cumple con } \\
\text { los requisitos } \\
\text { para presentar } \\
\text { candidatos, } \\
\text { además de } \\
\text { encontrarse } \\
\text { inscrita ante el } \\
\text { Ministerio del } \\
\text { Interior }\end{array}$ \\
\hline 26 & $\begin{array}{l}401 \text { del } 21 \\
\text { de febrero de } \\
2018\end{array}$ & $\begin{array}{l}\text { Eliécer } \\
\text { Crecencio - } \\
\text { Édgar Eduar } \\
\text { Perea - Hernán } \\
\text { Banguero }\end{array}$ & $\begin{array}{l}\text { Consejo Comunitario } \\
\text { Tabón Salado }\end{array}$ & $\begin{array}{l}\text { Aval otorgado } \\
\text { por organización } \\
\text { distinta al } \\
\text { consejo } \\
\text { comunitario }\end{array}$ & $\begin{array}{l}\text { La organización } \\
\text { cumple con } \\
\text { los requisitos } \\
\text { para presentar } \\
\text { candidatos, } \\
\text { además de } \\
\text { encontrarse } \\
\text { inscrita ante el } \\
\text { Ministerio del } \\
\text { Interior }\end{array}$ \\
\hline
\end{tabular}

(Continúa) 


\begin{tabular}{|c|c|c|c|c|c|}
\hline N. ${ }^{\circ}$ & Resolución & Candidato & Agrupación política & $\begin{array}{l}\text { Causa de la } \\
\text { solicitud }\end{array}$ & $\begin{array}{l}\text { Motivos de } \\
\text { la decisión - } \\
\text { Existencia de } \\
\text { plena prueba }\end{array}$ \\
\hline 27 & $\begin{array}{l}402 \text { del } 21 \\
\text { de febrero de } \\
2018\end{array}$ & $\begin{array}{l}\text { Jhon Arley } \\
\text { Murillo - Mario } \\
\text { David Gallego - } \\
\text { Liliana Yezmin } \\
\text { Zapata }\end{array}$ & $\begin{array}{l}\text { Consejo Comunitario } \\
\text { Ancestral de } \\
\text { Comunidades Negras } \\
\text { Playa Renaciente }\end{array}$ & $\begin{array}{l}\text { Aval otorgado } \\
\text { por organización } \\
\text { distinta al } \\
\text { consejo } \\
\text { comunitario }\end{array}$ & $\begin{array}{l}\text { La organización } \\
\text { cumple con } \\
\text { los requisitos } \\
\text { para presentar } \\
\text { candidatos, } \\
\text { además de } \\
\text { encontrarse } \\
\text { inscrita ante el } \\
\text { Ministerio del } \\
\text { Interior }\end{array}$ \\
\hline 28 & $\begin{array}{l}404 \text { del } 21 \\
\text { de febrero de } \\
2018\end{array}$ & Toda la lista & $\begin{array}{l}\text { Consejo Comunitario } \\
\text { de la Comunidad } \\
\text { Negra de la Calle } \\
\text { Larga del Río Dagua }\end{array}$ & $\begin{array}{l}\text { Aval otorgado } \\
\text { por organización } \\
\text { distinta al } \\
\text { consejo } \\
\text { comunitario }\end{array}$ & $\begin{array}{l}\text { La organización } \\
\text { cumple con } \\
\text { los requisitos } \\
\text { para presentar } \\
\text { candidatos, } \\
\text { además de } \\
\text { encontrarse } \\
\text { inscrita ante el } \\
\text { Ministerio del } \\
\text { Interior }\end{array}$ \\
\hline 29 & $\begin{array}{l}405 \text { del } 21 \\
\text { de febrero de } \\
2018\end{array}$ & Toda la lista & $\begin{array}{l}\text { Consejo Comunitario } \\
\text { de Comunidades } \\
\text { Negras Palenque } \\
\text { Vereda Las } \\
\text { Trescientas y } \\
\text { Municipio de Galapa }\end{array}$ & $\begin{array}{l}\text { Aval otorgado } \\
\text { por organización } \\
\text { distinta al } \\
\text { consejo } \\
\text { comunitario }\end{array}$ & $\begin{array}{l}\text { La organización } \\
\text { cumple con } \\
\text { los requisitos } \\
\text { para presentar } \\
\text { candidatos, } \\
\text { además de } \\
\text { encontrarse } \\
\text { inscrita ante el } \\
\text { Ministerio del } \\
\text { Interior }\end{array}$ \\
\hline 30 & $\begin{array}{l}409 \text { del } 21 \\
\text { de febrero de } \\
2018\end{array}$ & Toda la lista & $\begin{array}{l}\text { Consejo Comunitario } \\
\text { Rescate de las Varas }\end{array}$ & $\begin{array}{l}\text { Aval otorgado } \\
\text { por organización } \\
\text { distinta al } \\
\text { consejo } \\
\text { comunitario }\end{array}$ & $\begin{array}{l}\text { La organización } \\
\text { cumple con } \\
\text { los requisitos } \\
\text { para presentar } \\
\text { candidatos, } \\
\text { además de } \\
\text { encontrarse } \\
\text { inscrita ante el } \\
\text { Ministerio del } \\
\text { Interior }\end{array}$ \\
\hline 31 & $\begin{array}{l}411 \text { del } 21 \\
\text { de febrero de } \\
2018\end{array}$ & Toda la lista & $\begin{array}{l}\text { Consejo Comunitario } \\
\text { General del Río } \\
\text { Baudó y Sus } \\
\text { Afluentes }\end{array}$ & $\begin{array}{l}\text { Los candidatos } \\
\text { no acreditaron } \\
\text { su pertenencia } \\
\text { al consejo } \\
\text { comunitario }\end{array}$ & $\begin{array}{l}\text { Los consejos } \\
\text { comunitarios } \\
\text { tienen } \\
\text { autonomía para } \\
\text { determinar } \\
\text { quiénes son sus } \\
\text { integrantes y sus } \\
\text { representantes } \\
\text { en la Cámara. } \\
\text { Se demostró que } \\
\text { los candidatos } \\
\text { hacen parte de la } \\
\text { organización }\end{array}$ \\
\hline
\end{tabular}

(Continúa) 


\begin{tabular}{|c|c|c|c|c|c|}
\hline N. ${ }^{\circ}$ & Resolución & Candidato & Agrupación política & $\begin{array}{l}\text { Causa de la } \\
\text { solicitud }\end{array}$ & $\begin{array}{l}\text { Motivos de } \\
\text { la decisión - } \\
\text { Existencia de } \\
\text { plena prueba }\end{array}$ \\
\hline 32 & $\begin{array}{l}416 \text { del } 22 \\
\text { de febrero de } \\
2018\end{array}$ & Toda la lista & $\begin{array}{l}\text { Consejo Comunitario } \\
\text { del Río Yurumanguí }\end{array}$ & $\begin{array}{l}\text { Los candidatos } \\
\text { no acreditaron } \\
\text { su pertenencia } \\
\text { al consejo } \\
\text { comunitario }\end{array}$ & $\begin{array}{l}\text { Los consejos } \\
\text { comunitarios } \\
\text { tienen } \\
\text { autonomía para } \\
\text { determinar } \\
\text { quiénes son sus } \\
\text { integrantes y sus } \\
\text { representantes } \\
\text { en la Cámara. } \\
\text { Se demostró que } \\
\text { los candidatos } \\
\text { hacen parte de la } \\
\text { organización }\end{array}$ \\
\hline 33 & $\begin{array}{l}663 \text { del } 27 \\
\text { de febrero de } \\
2018\end{array}$ & Toda la lista & $\begin{array}{l}\text { Consejo Comunitario } \\
\text { Veredas Unidas Un } \\
\text { Bien Común }\end{array}$ & $\begin{array}{l}\text { Los candidatos } \\
\text { no acreditaron } \\
\text { su pertenencia } \\
\text { al consejo } \\
\text { comunitario }\end{array}$ & $\begin{array}{l}\text { Los consejos } \\
\text { comunitarios } \\
\text { tienen } \\
\text { autonomía para } \\
\text { determinar } \\
\text { quiénes son sus } \\
\text { integrantes y sus } \\
\text { representantes } \\
\text { en la Cámara. } \\
\text { Se demostró que } \\
\text { los candidatos } \\
\text { hacen parte de la } \\
\text { organización }\end{array}$ \\
\hline 34 & $\begin{array}{l}664 \text { del } 27 \\
\text { de febrero de } \\
2018\end{array}$ & $\begin{array}{l}\text { Gustavo Adolfo } \\
\text { Prado Cardona }\end{array}$ & $\begin{array}{l}\text { Consejo Comunitario } \\
\text { de Comunidades } \\
\text { Negras Obatala } \\
\text { Fundación Magdalena }\end{array}$ & $\begin{array}{l}\text { Los candidatos } \\
\text { no acreditaron } \\
\text { su pertenencia } \\
\text { al consejo } \\
\text { comunitario }\end{array}$ & $\begin{array}{l}\text { Los consejos } \\
\text { comunitarios } \\
\text { tienen } \\
\text { autonomía para } \\
\text { determinar } \\
\text { quiénes son sus } \\
\text { integrantes y sus } \\
\text { representantes } \\
\text { en la Cámara. } \\
\text { Se demostró que } \\
\text { los candidatos } \\
\text { hacen parte de la } \\
\text { organización }\end{array}$ \\
\hline
\end{tabular}


TABLA 3. PROCESOS PROMOVIDOS CONTRA CANDIDATOS INSCRITOS POR LA CIRCUNSCRIPCIÓN ESPECIAL INDÍGENA

\begin{tabular}{|c|c|c|c|c|c|}
\hline N. ${ }^{\circ}$ & Resolución & Candidato & $\begin{array}{c}\text { Circunscripción/Agrupación } \\
\text { política }\end{array}$ & $\begin{array}{l}\text { Causa de } \\
\text { la solicitud }\end{array}$ & $\begin{array}{l}\text { Motivos de } \\
\text { la decisión - } \\
\text { Existencia de } \\
\text { plena prueba }\end{array}$ \\
\hline 1 & $\begin{array}{l}165 \text { del } 6 \text { de } \\
\text { febrero de } \\
2018\end{array}$ & $\begin{array}{l}\text { Las } \\
\text { candidaturas }\end{array}$ & Senado - ASI, AICO y MAIS & $\begin{array}{l}\text { Inscripción } \\
\text { simultanea }\end{array}$ & $\begin{array}{l}\text { No existe } \\
\text { prohibición } \\
\text { que impida } \\
\text { la inscripción } \\
\text { simultánea de } \\
\text { listas para la } \\
\text { circunscripción } \\
\text { ordinaria y la } \\
\text { circunscripción } \\
\text { especial } \\
\text { indígena }\end{array}$ \\
\hline 2 & $\begin{array}{l}328 \text { del } 14 \\
\text { de febrero } \\
\text { de } 2018\end{array}$ & $\begin{array}{l}\text { Feliciano } \\
\text { Valencia } \\
\text { Medina }\end{array}$ & $\begin{array}{l}\text { Senado - Movimiento } \\
\text { Alternativo Indígena y Social }\end{array}$ & $\begin{array}{l}\text { Art. } 179 \\
\text { num. } 1 \mathrm{CP}\end{array}$ & $\begin{array}{l}\text { El demandado } \\
\text { no ha sido } \\
\text { condenado } \\
\text { judicialmente }\end{array}$ \\
\hline
\end{tabular}

TABLA 4. PROCESOS PROMOVIDOS CONTRA LOS CANDIDATOS INSCRITOS POR EL PARTIDO FARC

\begin{tabular}{|c|c|c|c|c|c|}
\hline N. ${ }^{o}$ & Resolución & Candidato & Circunscripción & $\begin{array}{l}\text { Causa de la } \\
\text { solicitud }\end{array}$ & $\begin{array}{c}\text { Motivos de la } \\
\text { decisión - Existencia } \\
\text { de plena prueba }\end{array}$ \\
\hline 1 & $\begin{array}{l}225 \text { del } 8 \text { de } \\
\text { febrero de } 2018\end{array}$ & $\begin{array}{l}\text { Seuxis } \\
\text { Pausias } \\
\text { Hernández } \\
\text { Solarte }\end{array}$ & $\begin{array}{l}\text { Cámara de } \\
\text { Representantes - } \\
\text { Atlántico }\end{array}$ & $\begin{array}{l}\text { Art. } 179 \text { num. } \\
1 \mathrm{CP}\end{array}$ & $\begin{array}{l}\text { No existe prueba } \\
\text { de condena judicial } \\
\text { ejecutoriada }\end{array}$ \\
\hline 2 & $\begin{array}{l}246 \text { del } 8 \text { de } \\
\text { febrero de } 2018\end{array}$ & $\begin{array}{l}\text { Álvaro Guaza } \\
\text { Carabalí }\end{array}$ & $\begin{array}{l}\text { Cámara de } \\
\text { Representantes - } \\
\text { Valle del Cauca }\end{array}$ & $\begin{array}{l}\text { Art. } 179 \text { num. } \\
1 \mathrm{CP}\end{array}$ & $\begin{array}{l}\text { Ausencia de } \\
\text { plena prueba de la } \\
\text { inhabilidad }\end{array}$ \\
\hline 3 & $\begin{array}{l}247 \text { del } 8 \text { de } \\
\text { febrero de } 2018\end{array}$ & $\begin{array}{l}\text { Pablo } \\
\text { Catatumbo } \\
\text { Torres }\end{array}$ & Senado - Nacional & $\begin{array}{l}\text { Art. } 179 \text { num. } \\
1 \mathrm{CP}\end{array}$ & $\begin{array}{l}\text { No existe prueba de } \\
\text { inhabilidades o de } \\
\text { condenas judiciales } \\
\text { ejecutoriadas }\end{array}$ \\
\hline 4 & $\begin{array}{l}248 \text { del } 8 \text { de } \\
\text { febrero de } 2018\end{array}$ & $\begin{array}{l}\text { Fanny } \\
\text { Maritza Fiallo }\end{array}$ & Senado - Nacional & $\begin{array}{l}\text { Art. } 179 \text { num. } \\
1 \mathrm{CP}\end{array}$ & $\begin{array}{l}\text { Ausencia de } \\
\text { plena prueba de la } \\
\text { inhabilidad }\end{array}$ \\
\hline 5 & $\begin{array}{l}249 \text { del } 8 \text { de } \\
\text { febrero de } 2018\end{array}$ & $\begin{array}{l}\text { María Edith } \\
\text { Patiño } \\
\text { Guerrero }\end{array}$ & $\begin{array}{l}\text { Cámara de } \\
\text { Representantes - } \\
\text { Valle del Cauca }\end{array}$ & $\begin{array}{l}\text { Art. } 179 \text { num. } \\
1 \mathrm{CP}\end{array}$ & $\begin{array}{l}\text { Ausencia de } \\
\text { plena prueba de la } \\
\text { inhabilidad }\end{array}$ \\
\hline 6 & $\begin{array}{l}252 \text { del } 8 \text { de } \\
\text { febrero de } 2018\end{array}$ & $\begin{array}{l}\text { Luis Alberto } \\
\text { Albán } \\
\text { Burbano }\end{array}$ & $\begin{array}{l}\text { Cámara - Valle del } \\
\text { Cauca }\end{array}$ & $\begin{array}{l}\text { Art. } 179 \text { num. } \\
1 \mathrm{CP}\end{array}$ & $\begin{array}{l}\text { El candidato registra } \\
\text { inhabilidades } \\
\text { suspendidas en virtud } \\
\text { del A. L. } 01 \text { de } 2017\end{array}$ \\
\hline
\end{tabular}

(Continúa) 


\begin{tabular}{|c|c|c|c|c|c|}
\hline N. ${ }^{\circ}$ & Resolución & Candidato & Circunscripción & $\begin{array}{l}\text { Causa de la } \\
\text { solicitud }\end{array}$ & $\begin{array}{c}\text { Motivos de la } \\
\text { decisión - Existencia } \\
\text { de plena prueba }\end{array}$ \\
\hline 7 & $\begin{array}{l}253 \text { del } 8 \text { de } \\
\text { febrero de } 2018\end{array}$ & $\begin{array}{l}\text { Victoria } \\
\text { Sandino }\end{array}$ & Senado - Nacional & $\begin{array}{l}\text { Art. } 179 \text { num. } \\
1 \mathrm{CP}\end{array}$ & $\begin{array}{l}\text { La candidata no } \\
\text { registra inhabilidades } \\
\text { ni condenas; presentó } \\
\text { acta de compromiso } \\
\text { de reincorporación } \\
\text { política }\end{array}$ \\
\hline 8 & $\begin{array}{l}254 \text { del } 8 \text { de } \\
\text { febrero de } 2018\end{array}$ & $\begin{array}{l}\text { Iván Luciano } \\
\text { Márquez } \\
\text { Marín }\end{array}$ & Senado - Nacional & $\begin{array}{l}\text { Art. } 179 \text { num. } \\
1 \mathrm{CP}\end{array}$ & $\begin{array}{l}\text { Las inhabilidades } \\
\text { y condenas } \\
\text { se encuentran } \\
\text { suspendidas; el } \\
\text { CNE mencionó que } \\
\text { no procedía la } \\
\text { revocatoria porque } \\
\text { esta significaría } \\
\text { desconocer la } \\
\text { obligación de cumplir } \\
\text { con el Acuerdo de } \\
\text { Paz }\end{array}$ \\
\hline 9 & $\begin{array}{l}322 \text { del } 14 \text { de } \\
\text { febrero de } 2018\end{array}$ & $\begin{array}{l}\text { Jairo } \\
\text { González } \\
\text { Mora }\end{array}$ & $\begin{array}{l}\text { Cámara - Bogotá } \\
\text { D.C. }\end{array}$ & $\begin{array}{l}\text { Inhabilidad } \\
\text { por ser el } \\
\text { candidato } \\
\text { objeto de } \\
\text { denuncias } \\
\text { por crímenes } \\
\text { graves contra } \\
\text { menores de } \\
\text { edad }\end{array}$ & $\begin{array}{l}\text { Se aportaron pruebas } \\
\text { inconducentes } \\
\text { para demostrar } \\
\text { la existencia de } \\
\text { la inhabilidad; } \\
\text { los testimonios } \\
\text { aportados no fueron } \\
\text { conducentes para } \\
\text { probar la inhabilidad } \\
\text { taxativa y no existe } \\
\text { plena prueba de esta }\end{array}$ \\
\hline 10 & $\begin{array}{l}330 \text { del } 14 \text { de } \\
\text { febrero de } 2018\end{array}$ & $\begin{array}{l}\text { Fancy María } \\
\text { Orrego } \\
\text { Medina }\end{array}$ & $\begin{array}{l}\text { Cámara de } \\
\text { Representantes - } \\
\text { Antioquia }\end{array}$ & $\begin{array}{l}\text { Art. } 179 \text { num. } \\
1 \mathrm{CP}\end{array}$ & $\begin{array}{l}\text { Ausencia de } \\
\text { plena prueba de la } \\
\text { inhabilidad }\end{array}$ \\
\hline 11 & $\begin{array}{l}331 \text { del } 14 \text { de } \\
\text { febrero de } 2018\end{array}$ & $\begin{array}{l}\text { Fabián } \\
\text { Ramírez } \\
\text { Cabrera }\end{array}$ & Senado & $\begin{array}{l}\text { Art. } 179 \text { num. } \\
1 \mathrm{CP}\end{array}$ & $\begin{array}{l}\text { Ausencia de } \\
\text { plena prueba de la } \\
\text { inhabilidad }\end{array}$ \\
\hline
\end{tabular}

